\title{
7. PALEOENVIRONMENTAL IMPLICATIONS OF MINERALOGIC AND GEOCHEMICAL DATA IN THE WESTERN FLORIDA STRAITS (LEG 77, DEEP SEA DRILLING PROJECT) ${ }^{1}$
}

Pierre Debrabant, Hervé Chamley, and Janine Foulon, Sédimentologie et Géochimie, Equipe de Recherche Associé 764, Centre National de la Recherche Scientifique, Université de Lille I, 59655 Villeneuve D'Ascq Cedex, France

\begin{abstract}
Clay mineralogic and inorganic geochemical investigations of Cretaceous and Cenozoic sediments of the western Gulf of Mexico lead to the following main conclusions. (1) Transition of lowermost Cretaceous continental to marine sedimentation is marked by a clay evaporitic stage, north of the Campeche Escarpment. (2) Existence of combined mineralogic and geochemical stratigraphy allows us to propose correlations between Sites 535 and 540, especially for the Albian. (3) Predominance of detrital clay assemblages is indicative of hot and variably humid continental climate until the early late Cenozoic. (4) Tectonic destabilization of the margins of Gulf of Mexico occurred at different periods, especially until the middle Cretaceous, with a mixed erosion of rocks and soils and temporary oxidized conditions of deposition. (5) Successive developments of confined perimarine basins occurred from the earliest Cretaceous until the Miocene, chiefly in the Florida area. The sources of inorganic materials were chiefly situated on the east of the studied area until the late Tertiary and after that in the Mississippi River basin. (6) Occasionally, volcanic activity influenced the clay mineralogy and mainly the geochemistry, and possibly contributed to the rather strong magnesian character of the deposition until the late Paleogene. (7) The argillaceous diagenesis is weak; variability of the carbonate diagenesis is marked by the relation $\mathrm{Sr}=\mathrm{f}(\mathrm{CaO})$ and chiefly depends on the depth of burial, the clay content, the porosity, and the geologic age.
\end{abstract}

\section{INTRODUCTION}

Six sites were drilled during Leg 77 in the western Florida Straits (Fig. 1, Table 1). Sites 536, 537, and 538 are located north of the Campeche Bank; fairly short drill sequences show the presence of continental basement and the transition from land to marine sediments. Sites 535, 539, and 540 are located more easterly, south of the Florida escarpment; more extensive drilling gave way to subcontinuous series from Berriasian to Pleistocene (Buffler, Schlager, et al., this volume). Clay mineralogic and inorganic geochemical studies were done on about 200 samples from 5 sites. Most interpretations presented here take into account previous data and discussions about the North Atlantic, already published in the Initial Reports (especially those for Legs 44, 47, 48, $50,76)$.

\section{ANALYTICAL PROCEDURES}

The following X-ray diffraction method was used. The samples are disassociated in water, then decarbonated in N/5 hydrochloric acid. Excess acid is removed by successive centrifuging. Microhomogenization affects deflocculation. The $<2 \mu \mathrm{m}$ fraction is collected by decantation, using Stokes' law; then oriented pastes are made on glass slides. A Philips 1730 diffractometer (copper radiation) is used to run the $\mathrm{X}$-ray diffraction scans at $2^{\circ} 2 \theta$ /minute. Three passages are carried out: (1) from 2.5 to $28.5^{\circ} 2 \theta$ on natural samples; (2) from 2.5 to $14.5^{\circ} 2 \theta$ on glycolated samples; (3) from 2.5 to $14.5^{\circ} 2 \theta$ on samples heated for 2 hours at $490^{\circ} \mathrm{C}$. Semiquantitative evaluations are based on peak heights and areas (Chamley, 1971). The heights of illite and chlorite 001 peaks (diagram for glycolated sample) are taken as references. By comparison with these values, values for smectite, palygorskite, sepiolite, vermiculite, and irregular mixed-layer clays are corrected by addition of peak height, whereas values for well-crystallized kaolinite are corrected by subtraction. The relative proportions of

\footnotetext{
${ }^{1}$ Buffler, R. T., Schlager, W., et al., Init. Repts. DSDP, 77: Washington (U.S. Govt.
} Printing Office). chlorite and kaolinite are determined from the ratio of peak heights (respectively 3.54 and $3.58 \AA$ ): when this ratio is 1 , the amount of chlorite is assumed to be twice that of kaolinite. Data are given in percentages, and the relative error is about $\pm 5 \%$.

Electronmicroscopy observations have been done with a Siemens transmission microscope, on $<8 \mu \mathrm{m}$ particles deposited on copper grids covered by a collodion film, after carbonate removal and physical deflocculation.

The following geochemical procedure was used. The samples are dried at $105^{\circ} \mathrm{C}$, then crushed and homogenized. Then, $0.2 \mathrm{~g}$ of the samples are submitted to alkaline fusion, solubilized by $\mathrm{HCl}$, and diluted to $100 \mathrm{ml}$; another $0.2 \mathrm{~g}$ of sample are submitted to fluoronitric treatment in a bomb at $150^{\circ} \mathrm{C}$ and 50 bars for $\mathrm{SiO}_{2}$ and $\mathrm{Al}_{2} \mathrm{O}_{3}$ determination. Also, $1 \mathrm{~g}$ of sample is submitted to fluoroperchloric treatment, solubilized by $\mathrm{HCl}$, and diluted to $100 \mathrm{ml}$. The dilutions are used for colorimetric analysis of $\mathrm{TiO}_{2}$ and $\mathrm{P}_{2} \mathrm{O}_{5}$ and spectrophotometric analysis of other major and trace elements by atomic absorption in flame, with a 5000 Perkin Elmer automatized spectrophotometer.

\section{NORTH OF CAMPECHE ESCARPMENT}

\section{Site $\mathbf{5 3 6}$}

Located immediately at the northeastern foot of the Campeche terrace, Site 536 sediments have been sparsely recovered. Only four samples of Cenozoic calcareous oozes and chalks (Units I and II) have been studied for their clay composition (Fig. 2). Miocene sediments are rich in smectites associated with illite and kaolinite, with minor quantities of chlorite, irregular mixed-layer clays, palygorskite, quartz, feldspars, and clinoptilolite. Paleocene deposits include more palygorskite and small amounts of sepiolite. This composition is similar to the one described in the same area for Leg 10 contemporaneous materials (Zemmels and Cook, 1973) and will be discussed together with data from Sites 537 and 538.

\section{Site $\mathbf{5 3 7}$}

Located on a submarine high northwest of Site 536 (Fig. 1), Site 537 bottomed in quartzites and crystalline 


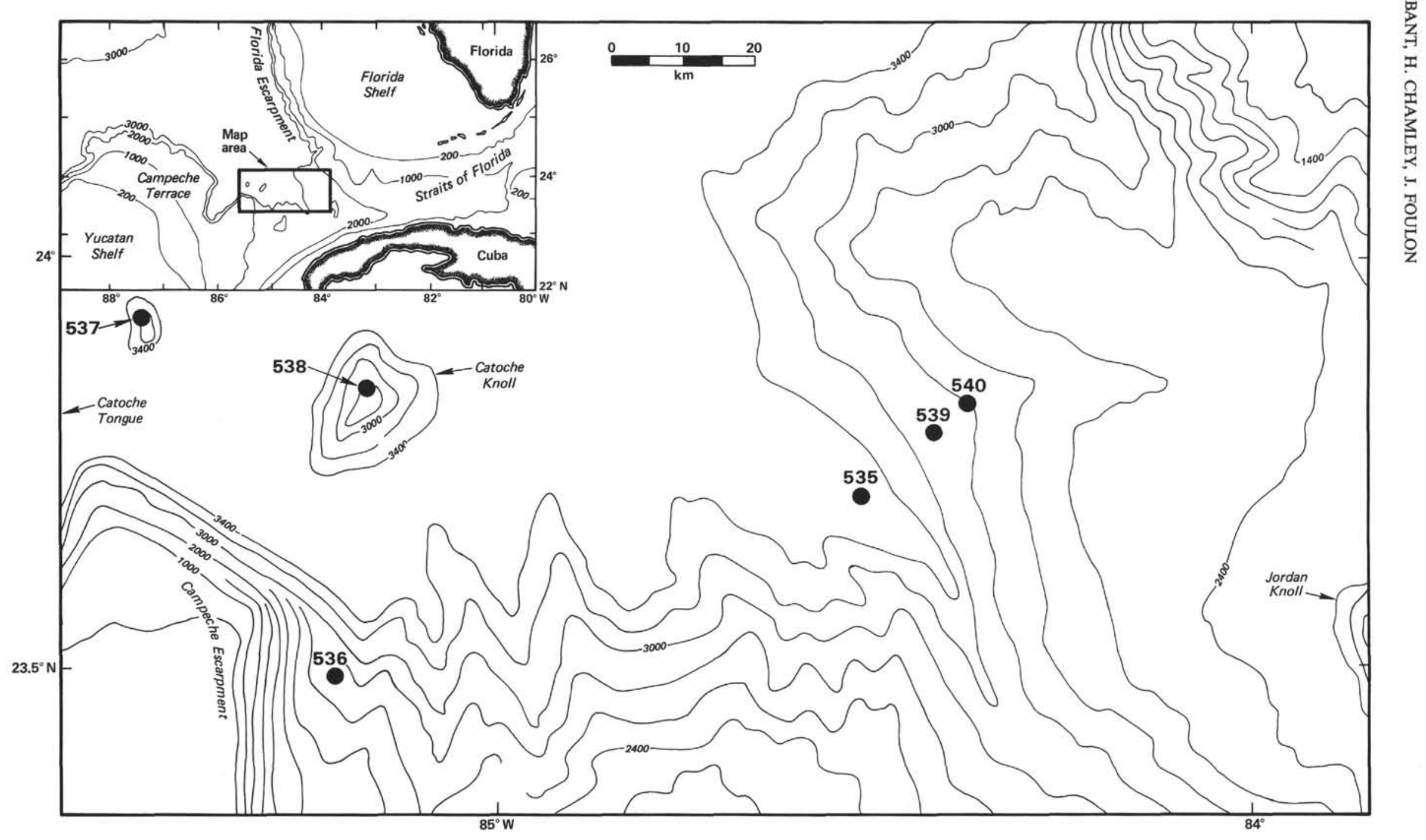

Figure 1. Location of Leg 77 drill sites with map area (bathymetry in meters). 
Table 1. Sites drilled during DSDP Leg 77.

\begin{tabular}{|c|c|c|c|c|c|c|}
\hline Site & $\begin{array}{l}\text { Latitude } \\
\text { (all north) }\end{array}$ & $\begin{array}{l}\text { Longitude } \\
\text { (all west) }\end{array}$ & $\begin{array}{c}\text { Water } \\
\text { depth } \\
\text { (m) }\end{array}$ & $\begin{array}{l}\text { Penetration } \\
\text { (m) }\end{array}$ & $\begin{array}{l}\text { Oldest } \\
\text { rocks } \\
\text { recovered }\end{array}$ & $\begin{array}{c}\text { Number } \\
\text { of } \\
\text { samples } \\
\text { (this study) }\end{array}$ \\
\hline 535 & $23^{\circ} 42.48^{\prime}$ & $84^{\circ} 30.97^{\prime}$ & 3450 & 714 & $\begin{array}{l}\text { Berriasian } \\
\text { limestone }\end{array}$ & 93 \\
\hline 536 & $23^{\circ} 29.39^{\prime}$ & $85^{\circ} 12.58^{\prime}$ & 2790 & 213 & Dolomite & 4 \\
\hline 537 & $23^{\circ} 56.01^{\prime}$ & $85^{\circ} 27.62^{\prime}$ & 3123 & 225 & $\begin{array}{l}\text { Arkose } \\
\quad \text { (Jurassic?) }\end{array}$ & 5 \\
\hline 538 & $23^{\circ} 50.95^{\prime}$ & $85^{\circ} 09.93^{\prime}$ & 2742 & 332.5 & $\begin{array}{l}\text { Crystalline } \\
\text { basement }\end{array}$ & 36 \\
\hline 540 & $23^{\circ} 49.73^{\prime}$ & $84^{\circ} 22.25^{\prime}$ & 2926 & 745.5 & $\begin{array}{l}\text { Albian } \\
\quad \text { limestone }\end{array}$ & 55 \\
\hline
\end{tabular}

phyllites. We studied only a few samples of the lowermost sediments (Berriasian?) and of the upper Paleocene (Figs. 2 and 3A; Appendix).

The varicolored clayey sandstones of Core $13(178 \mathrm{~m}$ below the mudline) are devoid of carbonates, poor in transition elements (Fe, Mn, Ni, Co, Cu; see Index $\mathrm{Mn}^{* 2}$, Fig. 3A), and rich in silica and potassium. The relative abundance of the coarse fraction is responsible for the high $\mathrm{SiO}_{2} / \mathrm{Al}_{2} \mathrm{O}_{3}$ ratio. This precludes the chemical expression of the noticeable magnesium content of the clay fraction, which essentially consists of long and well-preserved bundles of palygorskite (Plate 1, Figs. 2-3).

The clayey limestones and silty mudstones of Core 11 (Berriasian?, $160 \mathrm{~m}$ below the sediment/water interface) show a highly diversified clay assemblage: chlorite, illite, illite-smectite and chlorite-smectite irregular mixedlayer clays, medium-crystallized smectite, kaolinite, palygorskite, and sepiolite, associated with quartz, feldspars, and amphiboles (Plate 1, Fig. 1). The geochemistry is marked by the appearance and increase of calcite and dolomite with little strontium, while transition ele-

$$
{ }^{2} \text { Index } \mathrm{Mn}^{*}=\log \left[\frac{\frac{\text { Mn samples }}{\text { Mn shales }}}{\frac{\text { Fe samples }}{\text { Fe shales }}}\right]
$$

ments are more abundant (i.e., $\mathrm{Mn}=868 \mathrm{ppm}$; see Index Mn*, Fig. 3A).

The calcareous oozes of Core 3 (88.9 m, upper Paleocene) contain much smectite with minor amounts of various clay and nonclay minerals, and more transition elements (especially $\mathrm{Mn}$ ) than below. The clay composition is very similar to that of Site 536 at the same period (Fig. 2).

Despite their clastic character, strongly marked by their silica content, the basal sandstones contain clays typically formed under confined chemical conditions (Millot, 1964). The high abundance of palygorskite probably reflects the transition environments between land and sea, when the marine transgression developed on the periphery of the Gulf of Mexico. These environments, Jurassic to earliest Cretaceous in age, favored the development either of saline evaporites (Buffler et al., 1981), or of clay evaporites such as palygorskite. The detrital character of the sedimentation, associated with the abundance and the exceptional preservation of chemical clays, suggests a reworking from short distances, without noticeable alteration during erosion and transport. The abundance of $\mathrm{SiO}_{2}$ and $\mathrm{K}$ indicates the proximity of the continental crust. Thus the association of evaporitic clays and coarse quartzose sands appears as a good marker of both transition from terrestrial to marine sedimentation and strong erosion and reworking.

Further downhole (Core 11), the mineral diversification, the development of calcareous organisms, and the water oxidation suggested by $\mathrm{Mn}^{*}$ values (Debrabant and Foulon, 1979) reflect the development of open marine conditions, favoring the water exchanges, planktonic life, and the large distribution by seaways of mineral suspensions reworked from both continental rocks and soils.

During the Paleocene (Core 3) the sedimentation conditions were those of an oxygenated marine basin, with abundant smectite chiefly issued from poorly drained continental soils (Chamley, 1979), perhaps also from

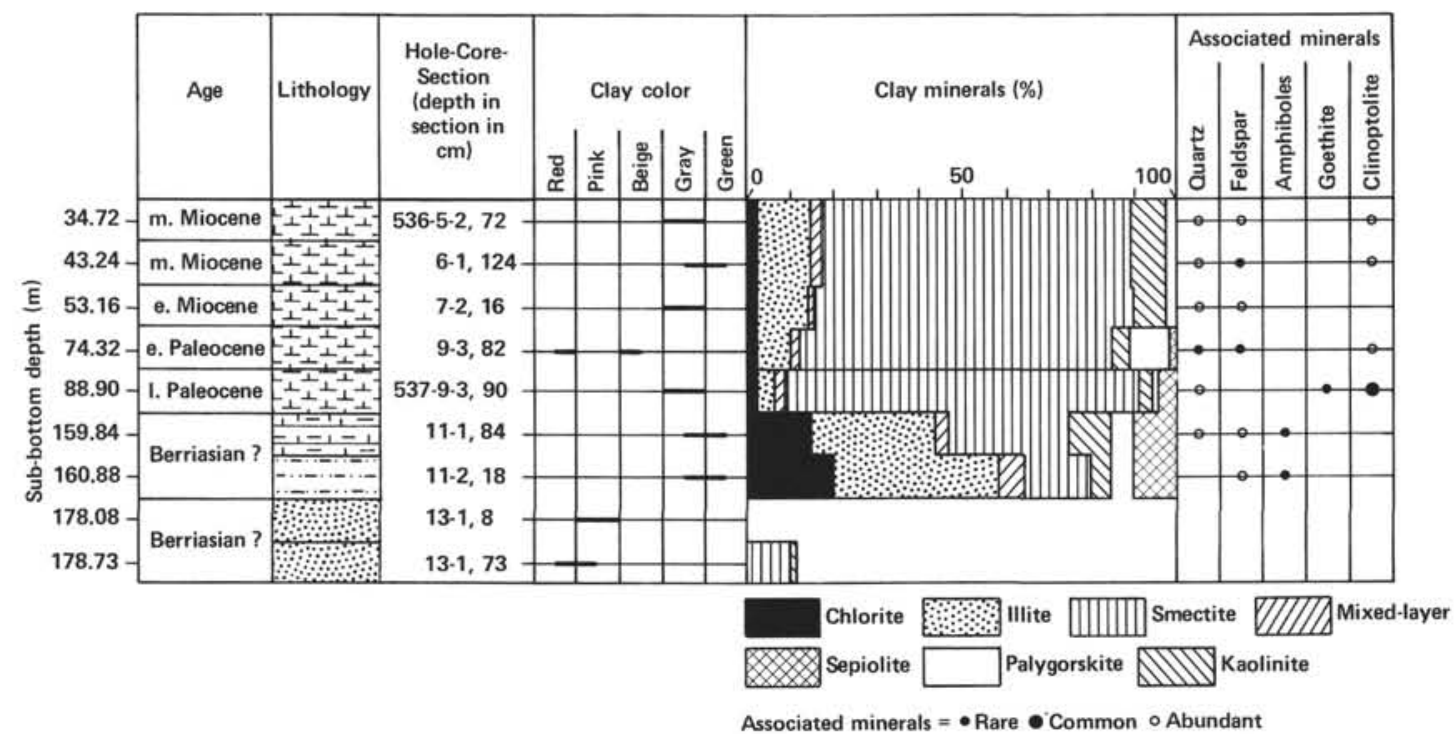

Figure 2. Holes 536 and 537 clay mineralogy. See Introduction and Explanatory Notes (this volume) for lithology symbols. 

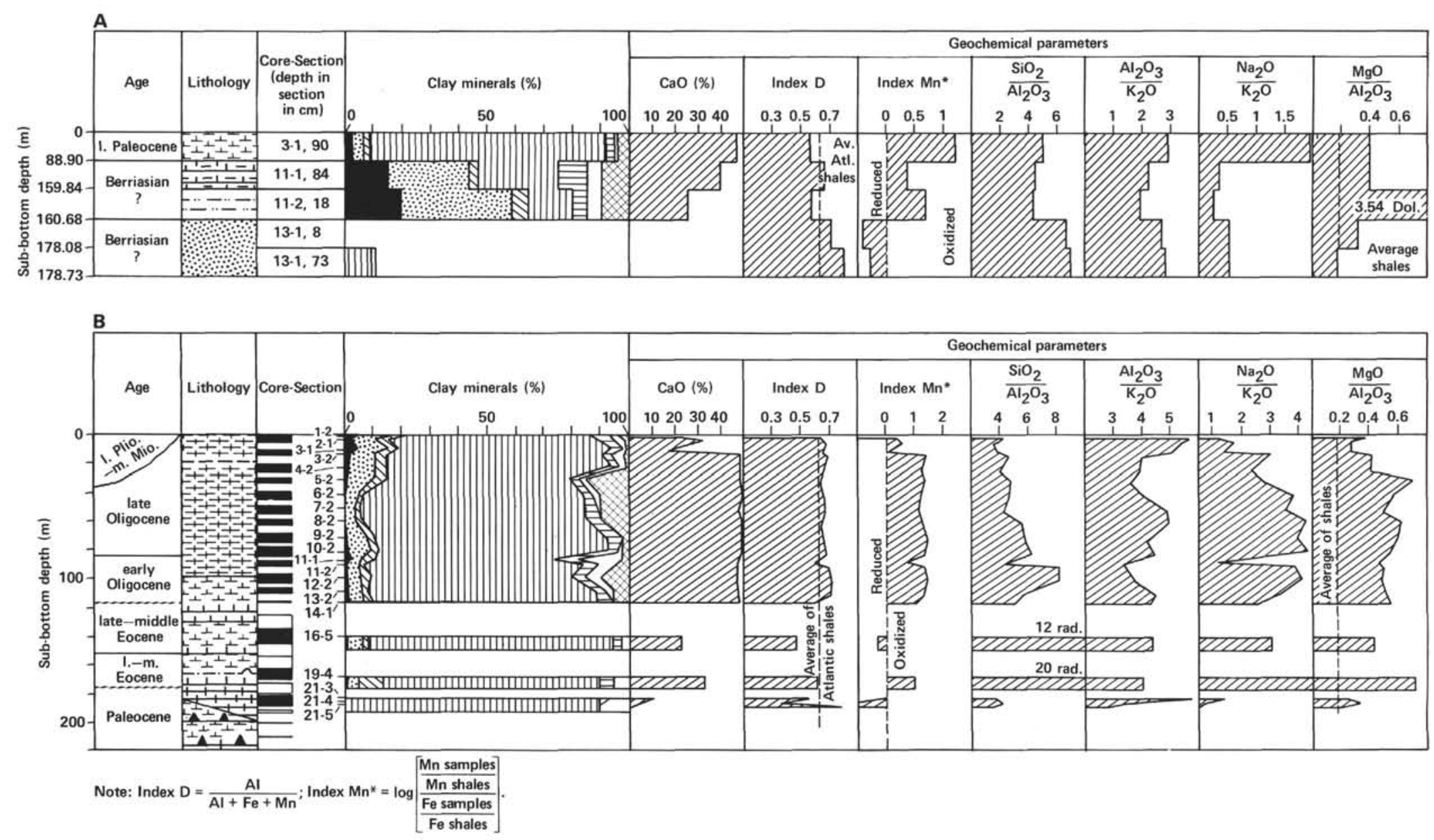

Figure 3. Holes 537 (A) and 538A (B), comparison of geochemical and mineralogic data. See Figure 2 for key to symbols. Av. = average; Atl. = Atlantic; Dol. $=$ dolomite. 
Cuban volcanic material, and associated with minerals derived from both rocks and soils.

\section{Hole 538A}

Hole 538A was drilled on the Catoche Knoll (north of Site 536, south-southeast of Site 537), where the following rocks were recovered: upper Pliocene to upper Oligocene foraminiferal and nannofossil oozes with terrigenous clays; upper Oligocene to middle Eocene calcareous oozes, chalks, marls, mudstones with occasional volcanic glass; middle Eocene to uppermost Albian chalks and claystones with oxidized surfaces and some ash levels; Upper Cretaceous to lowermost Cretaceous bioclastic limestones; and continental crust consisting of various and diversely altered gneiss, amphibolites, and diabases.

Generally not abundant, the clay fraction extracted after the grinding of diabases, amphibolites, and other crystalline or volcanic rocks shows the presence of abundant smectite and subordinate chlorite, with variable amounts of associated quartz, feldspars, iron oxides, and amphiboles (Fig. 4). This assemblage typically reflects the in situ alteration of crystalline and magnesium-rich rocks typical of the continental crust.

The Cretaceous bioclastic limestones (Cores 29, 24) appear to contain much illite and/or smectites, the supply of which reflects various conditions in the nature of rocks and the formation of soils, with changing grain sorting during deposition (smectite is not favored under conditions of high energy, and illite is rather favored).

The Upper Cretaceous to Paleogene chalks and claystones (Cores 22, 21) are very rich in smectite, a part of which could be of volcanogenic origin, as suggested by the abundance of $\mathrm{Zn}, \mathrm{Cr}, \mathrm{Cu}$, and locally of $\mathrm{Li}$ and $\mathrm{Ti}$ (Sample 538A-21-4, $124 \mathrm{~cm}$ ) (Fig. 3 and 4; Appendix). Long and flexuous fibers of palygorskite, sometimes accompanied by goethite aggregates (Plate 1, Figs. 5-6), could develop from the reworking of marginal evaporitic basins, as suggested by Site 537 data. Some levels show a very high content of $\mathrm{Fe}\left(18 \% \mathrm{Fe}_{2} \mathrm{O}_{3}\right.$ in Sample $538 \mathrm{~A}-21-4,124 \mathrm{~cm}$ ), probably determined by local development of hardgrounds (Buffler, Schlager, et al., this volume).

The Tertiary clay assemblages are very diversified but strongly dominated by the smectite abundance. The clay diversity expresses the water mass exchanges, the smectite preponderance coming from continental pedogenesis and locally from volcanism (e.g., 538A-16-5, $20 \mathrm{~cm}$, Eocene: abundance of $\mathrm{Fe}, \mathrm{Cu}, \mathrm{Cr}$, Ni). Illite, chlorite, and mixed-layer clays tend to increase slightly upwards, probably because of the worldwide cooling, which would not favor the soil development on continents (Chamley, 1979). Fibrous clays occur throughout the Tertiary in variable amounts, with a significant increase of palygorskite in the lower Oligocene, and of sepiolite and $\mathrm{MgO}$ in the upper Oligocene (Figs. 3B and 4; Plate 1, Fig. 4): these minerals, systematically scattered among other clay species, probably issue from the erosion of evaporitic facies, especially developed in Florida (e.g., Weaver and Beck, 1977). The calcareous sedimentation developing from Oligocene sediments upwards is marked by still high contents of $\mathrm{Sr}$, which suggest that a noticeable part of nannofossils was preserved from diagenetic dissolution and did not contribute to the lithification. Note the existence of a strong geochemical signal at the boundary between lower and upper Oligocene (538A-11-1, $70 \mathrm{~cm}$ :

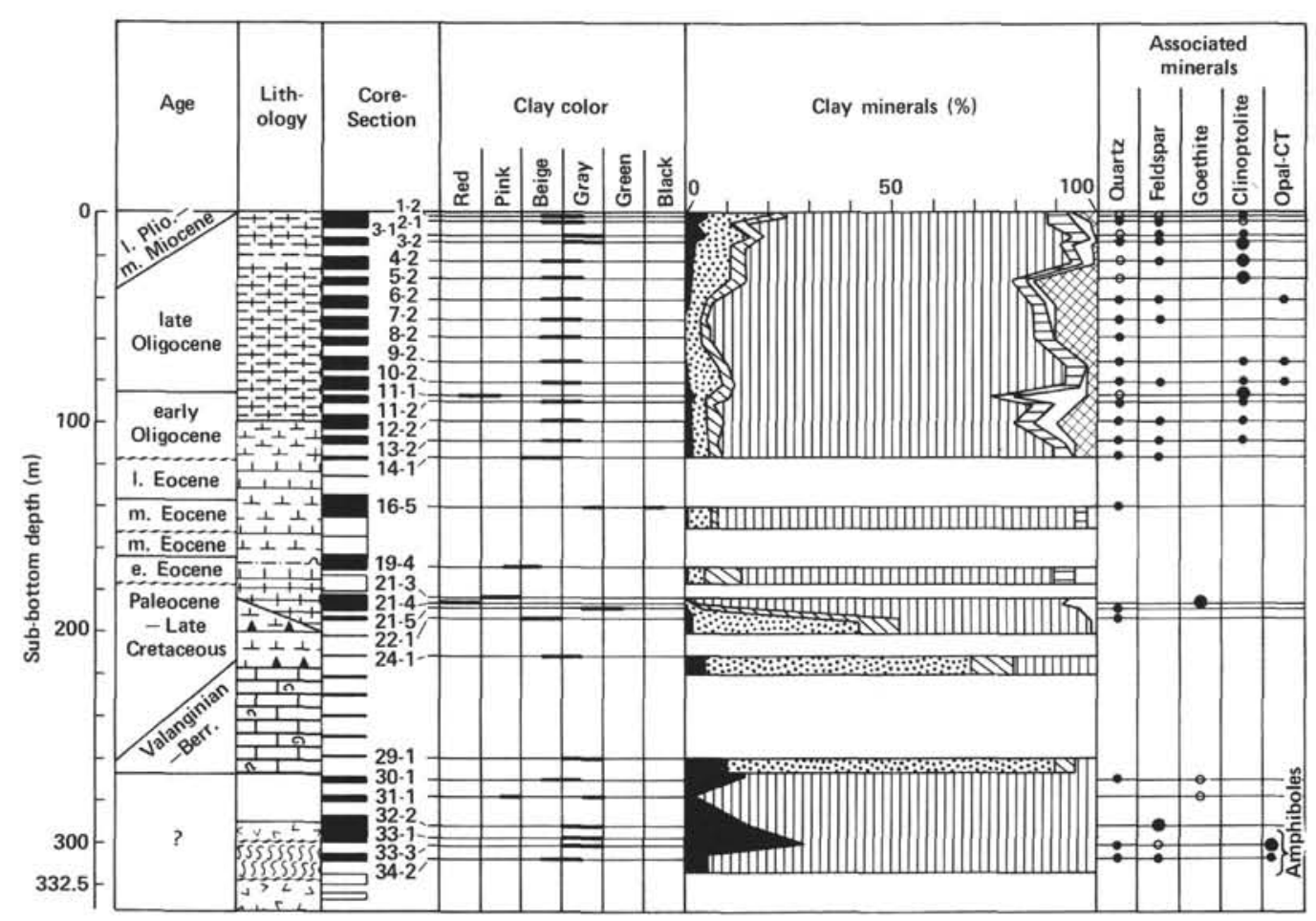

Figure 4. Site 538 clay mineralogy. See Figure 2 for symbols. 
$\mathrm{Na}, \mathrm{Si}, \mathrm{Mn}$ decrease), associated with a palygorskite peak (Fig. 3B).

\section{SOUTH OF THE WESTERN FLORIDA ESCARPMENT}

Both Sites 535 and 540 were drilled fairly close to each other (Fig. 1), allowing recovery of complementary sedimentary sections. Site 535 is the deepest $(3450 \mathrm{~m}$ water depth) and chiefly includes Early Cretaceous and Pleistocene sediments. Site 540 is the shallowest $(2926 \mathrm{~m})$ and mainly consists of Albian, Upper Cretaceous, and lower Cenozoic deposits.

\section{Site $\mathbf{5 3 5}^{\mathbf{3}}$}

Five lithologic units were identified in the 79 cores of Hole 535: Holocene-late Pleistocene quickly deposited clayey oozes, with variable amounts of carbonates, continental organic matter, and sometimes glauconite (Unit I, Cores 535-1 to Section 535-17-7, 0-154.3 m); Albian resedimented shallow-water carbonates, with limestonemarlstone alternations increasing downhole (Unit II, Core 535-18 to Section 535-42-4, 154.3-387.5 m); lower Albian to upper Hauterivian, olive to gray cyclic limestone and marly limestone deposits (Unit III, Sections 535-42-4 to 535-51-2, 387.5-466.5 m); upper Hauterivian to lower Valanginian gray to blackish alternation of limestones and marly limestones (Unit IV, Sections 535-51-2 to 535-68-2, 466.5-613.2 m); lower Valanginian to upper Berriasian greenish gray alternations of limestones and marly limestones, with local hard ground deposits, and sometimes glauconite and phosphorite (Unit $\mathrm{V}$, Sections 535-68-2 to 535-79-1, 613.2-714 m).

The largest part of Unit V (Cores 72 to 79) is characterized by the relative abundance of illite and kaolinite, with minor quantities of palygorskite, quartz, and feldspars. These minerals represent two maxima, one in the late Berriasian and one in the early Valanginian (Fig. 5). This mineralogic association, indicative of a strong continental erosion in a tectonically unstable context (Chamley, 1979), corresponds to a highly detrital character of geochemical parameters (Index D, ${ }^{4}$ Fig. 6) and to an oxidized environment extending to Core 65 (Index Mn*). The independence between $\mathrm{Sr}$ and $\mathrm{Ca}$, occurring along the whole Cretaceous recovered sediments, points to the intensity of the carbonate diagenesis (Appendix) (Debrabant and Foulon, 1979; Maillot and Robert, 1980). The high Fe content of 535-72-4, $68 \mathrm{~cm}$, following the deposit of Mn and the peculiar development of an oxidized context, characterizes the occurrence of a hardground deposit.

The major part of Valanginian and Hauterivian sediments (Cores 71 to 48), occupying Lithologic Unit IV and the transition with adjacent units, is marked by a mineralogic homogeneity of the clay fraction. Smectites are very abundant and well crystallized, showing common cloudy sheets on micrographs (Plate 2, Fig. 6). As-

\footnotetext{
${ }^{3}$ This manuscript was completed before the new biostratigraphic data for Site 535 were available. Because the previous stratigraphy (based on calcareous microfossils; see text and illustrations) shows sedimentologic, mineralogic, and geochemical correlations between Sites 535 and 540 , we preferred to keep this chapter unchanged.

${ }^{4}$ Index $\mathrm{D}=\mathrm{Al} / \mathrm{Al}+\mathrm{Fe}+\mathrm{Mn}$.
}

sociated minerals are generally rare and quantitatively nearly invariable (illite, illite-smectite irregular mixedlayer clays, kaolinite, quartz, and sometimes feldspars and goethite). There does not appear any significant relationship between the smectite abundance and the local existence of ash beds. The dominant clay mineral is of a AlFe type and seems to have resulted chiefly from the erosion of continental soils, which formed massively under stable and warm conditions in a large part of most of the peri-Atlantic areas during the Cretaceous (Chamley, 1979). The geochemical parameters show between Sections 535-64-4 and 535-50-3 the passage from an oxidized to a reduced environment, with fluctuations in the $\mathrm{Al} / \mathrm{Fe}$ ratio (Index D) caused by local pyrite crystallizations. From Core 58 upwards a silico-magnesian context develops, corresponding to the frequent existence of dolomitic beds (more than $30 \%$ dolomite in Sample 535$57-4,56 \mathrm{~cm}$ ). A positive correlation occurs between the $\mathrm{CaO}$ abundance and the Index $\mathrm{Mn}^{*}$ (which is proportional to the oxidation status); this agrees with the statement in site chapter, Sites 535, 539, and 540 (this volume) that the $\mathrm{pH}$ decrease of bottom waters during lowoxygenated stages determined a carbonate-depleted sedimentation.

The Barremian-Aptian-Albian period (Cores 47 to 18, Lithologic Units III and II) shows a highly changing clay sedimentation. A large-scale alternation of layers rich in smectite and those rich in illite/kaolinite/mixed layer clays develops, independently of the limestone-marly limestone alternation. Other minerals occur locally, especially during the period marked by illite increases: chlorite, palygorskite, quartz, feldspars, and amphiboles. The main illite-rich stages developed during the Barremian (Core 46), the earliest Albian (Cores 42, 41), the middle Albian (Core 35), the transition from middle to late Albian (Cores 32 to 25), and the late Albian (Cores 24 to 21). Most of these "illite peaks" occupy Lithologic Unit II, in which numerous reworked calcareous debris and resedimentation structures occur (site chapter, Sites 535,539 , and 540 , this volume). The variable clay sedimentation probably resulted from a global tectonic instability of the Gulf of Mexico margins from Barremian to Albian, favoring continental erosion/submarine reworking and periodically interrupted by relaxation stages. The instability itself is probably connected to the widening of the marine basin. The first illite peak is preceded by a general geochemical break (Fig. 6; Appendix), especially marked by a decrease of $\mathrm{Ca}$ and an increase of Fe contents. The environment becomes more oxidized and the Index D progressively reaches values close to the average values of the Atlantic Ocean (0.63). From Cores 42 to 35 (early Albian), reducing conditions determine various precipitations of $\mathrm{Mn}, \mathrm{Fe}$, and $\mathrm{Si}$ carbonates, leading to strong variations of Index D; these precipitations (among which are celestite and strontianite) agree with the carbonate diagenesis in closed geochemical systems (Kinsman, 1969).

The Quaternary (Cores 17 to 1 , Unit I) is characterized by a lithologic, mineralogic, and geochemical homogeneity. The clay assemblage is very diversified and dominated by well-crystallized smectite accompanied by 
illite, chlorite, kaolinite, chlorite-smectite, and illite-smectite irregular mixed-layer clays, quartz, feldspars, amphiboles, and goethite. This assemblage typically corresponds to the Mississippi River contribution to the Quaternary marine sedimentation (i.e., Grim and Johns, 1954; Johns and Grim, 1958; Pinsak and Murray, 1960; van Andel and Poale, 1960; Mélières, 1967; Zemmels and Cook, 1973; Chamley and Kennett, 1976). Minor amounts of palygorskite and sepiolite, occasionally associated with clinoptilolite and opal CT, probably reflect an additional contribution from Florida, where these minerals abundantly occur in late Cenozoic sedimentary rocks (Weaver and Beck, 1977). The detrital character of the mineral sedimentation is corroborated by the Index $\mathrm{D}$ and the $\mathrm{MgO} / \mathrm{Al}_{2} \mathrm{O}_{3}$ ratio. Some fluctuations in the $\mathrm{CaO}$ content correspond to more oxidized conditions (Index $\mathrm{Mn}$ ). The relative abundance of $\mathrm{Sr}$ in the more recent sediments probably results from the presence of aragonitic shells of pteropods (site chapter, Site 535 , this volume).

\section{Site 540}

The lower half of Hole 540 penetrated Albian sediments; the cyclic character is less pronounced than at Site 535. Six lithologic units were identified and systematically studied for a mineralogy and geochemistry: Pleistocene clayey oozes (Unit I, Core 1, 0-4.5 m); upper Miocene to upper Paleocene calcareous oozes, chalks, marly chalks, with thin ash layers and slumping in the lower part of the unit (Unit II, Core 540-2, to Section 540-302, 4.5-272.3 m); lower Paleocene to lower Cenomanian conglomeratic marls and volcanic sands, with gradedbedded sandstones in the upper part of the unit, a mixture of deep-water and shallow-water sediments, and numerous evidences of resedimentation (Unit III, Sections 540-30-2 to 540-36-1, 272.3-328.1 m); lower Cenomanian to upper Albian cherty limestones (Unit IV, Cores 36 to 53, 328.1-498.5 m); upper to middle Albian limestones (Unit V, Cores 53 to 76, 498.5-717 m); middle to lower Albian bioclastic limestones, with shallowwater debris (Unit VI, Cores 76 to 79, 717-745.5 m).

The lower part of Albian deposits (Cores 79 to 60, Unit VI and major part of Unit V) shows an irregular clay sedimentation (Fig. 5), characterized either by illite, kaolinite, irregular mixed-layer clays, and chlorite (middle Albian, middle to late Albian transition, lower late Albian; Plate 2, Fig. 5), or by abundant smectites (upper part of middle Albian). The smectite maximum corresponds to an increase in $\mathrm{Ca}, \mathrm{Na}, \mathrm{Mg}$, and $\mathrm{Si}$ contents (Fig. 7; Appendix) and also roughly to the Lithologic Subunit $\mathrm{Vb}$. These mineralogic alternations, not connected with peculiar lithologic variations, resemble those identified in the Albian of Site 535; in the same way as at Site 535, they seem to reflect a rough cyclicity in the tectonic activity on the margins of the Gulf of Mexico: stable periods marked by the pedogenic development of smectites, unstable periods marked by a renewal of both rocks and soil erosion. The detrital influence on geochemistry is similar in the two sites (Index D, Figs. 6 and 7; trace elements, Fig. 8), and the environment is poorly oxidizing (Index $\mathrm{Mn}^{*}$ ). The main mineral differ- ences between both sites consist of higher contents of "illite group" minerals, with various associated nonclay minerals (quartz, feldspars, amphiboles, goethite), at Site 535. $\mathrm{Cr}$ appears to be connected with the "illite group." Other geochemical differences are much more marked: Site 540 shows higher contents in $\mathrm{CaO}$ and lesser diagenetic precipitations than Site 535 Unit II (dolomite, Fe and Mn oxidations, Sr mineralizations).

The upper part of Site 540 Albian deposits shows mineralogic patterns similar to the Late Cretaceous sediments (Cores 59 to 33, Lithologic Unit IV with transition to adjacent units). From upper Albian to Maestrichtian, smectites are abundant and highly crystallized and accompanied by only accessory amounts of other minerals (chiefly illite and palygorskite, each mineral forming $5-20 \%$ of the clay fraction). Opal CT and clinoptilolite locally exist (especially in Cores 49 to 42 ). Smectites occur as cloudy sheets, and palygorskite as short and broken fibers (Plate 2, Fig. 4). This clay assemblage probably results chiefly from the reworking of continental soils and of alkaline sediments, developed on poorly sloped areas on the periphery of the Gulf of Mexico, under hot climatic conditions with strong humidity contrasts, (such conditions occurred at the same time on the eastern North Atlantic margins: Chamley et al., 1979; Debrabant et al., 1979). The chemical environment was first more oxidizing than before and also marked by relatively high values of $\mathrm{Ca}, \mathrm{Na}$, and $\mathrm{Mg}$ (Cores 60 to 49); after that it was temporarily more reducing (Cores 48 to 45 ), until it became permanently oxidizing (Fig. 7). The reworking of fibrous clays is marked by increased amounts of $\mathrm{Mg}, \mathrm{Na}$, and $\mathrm{Sr}$ at different levels, while local diagenetic processes such as dolomitization seem to develop (i.e., Core 37).

The Paleocene sediments (Cores 32 to 30 ) are poorly recovered. They contain the highest amounts of smectite in the whole sedimentary column. Despite the common morphology of the smectite sheets (Plate 2, Fig. 3) and the rareness of the volcanic debris, the clay mineralogy could locally and partly depend on the volcanic activity, as suggested by the relative abundance of $\mathrm{Fe}, \mathrm{Mn}, \mathrm{Li}$, and $\mathrm{Na}$ (Fig. 7; Appendix). This resembles the synchronous levels of Core 538A-21 (Appendix).

During the Eocene (Cores 29 and 28) sepiolite occurred for the first time, accompanied by various minerals including palygorskite, clinoptilolite, opal CT, and the common smectite-rich assemblage. The presence of magnesian fibrous clays is not expressed by the geochemistry, probably because of the mask determined by the abundant carbonate fraction. The presence of numerous resedimentation structures suggests that, as in a large part of the Atlantic Ocean, fibrous clays chiefly resulted from the reworking of evaporitic clays formed on perimarine basins (Chamley, 1979).

The Oligocene deposits (Cores 18, 17, 13) contain either abundant smectite with various associated species, or abundant smectite and sepiolite (Plate 2, Fig. 2). In the latter case, the magnesian character of the mineralogy is expressed by geochemical parameters. The pelagic sedimentation is carbonated and well oxygenated. $\mathrm{Sr}$ is closely related to $\mathrm{CaO}$, suggesting restricted diagenetic 


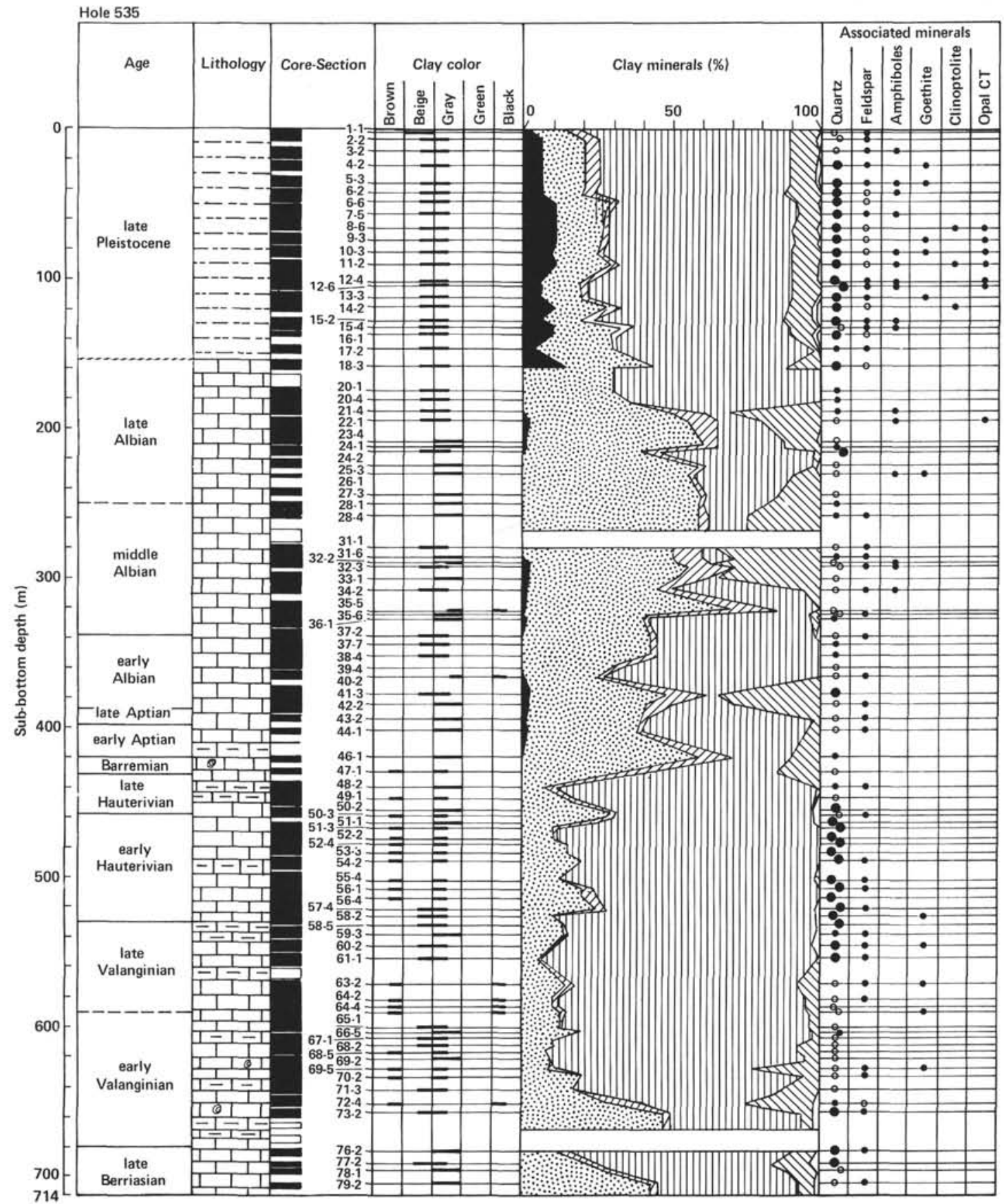

Figure 5. Holes 535 (water depth $3455.5 \mathrm{~m}$ ) and 540 (water depth $2940.5 \mathrm{~m}$ ), clay mineralogy. See Figure 2 for symbols.

modifications. The good state of preservation of fibrous minerals suggests a rather close origin or rapid transport and burying.

From Miocene upwards (Cores 6 to 1, top of Unit II and Unit I), the clay assemblages rapidly reach the composition of modern sediments from the Gulf of Mexico. Smectite abundance slightly decreases, but chlorite and irregular mixed-layer clays become ubiquitous, and illite, kaolinite, quartz, and feldspars increase. The top of Hole 540 is very similar to the top of Hole 535, both mineralogically and geochemically, and chiefly corresponds to the detrital supply of Mississippi River under late Cenozoic climatic conditions (e.g., Johns and Grim, 1958; Mélières, 1967). Note the steady occurrence of fi- brous clays in small amounts, with local increases of abundance (sepiolite in 540-5-3, $55 \mathrm{~cm}$; Plate 2, Fig. 1); these reworked minerals reflect the genesis they show in the perimarine environments of the Florida coast until the early-middle Miocene (Weaver and Beck, 1977). Note also the high manganiferous character of the Pleistocene sedimentation (Core 1, $1665 \mathrm{ppm}$ of $\mathrm{Mn}$ ), possibly correlated with higher bottom-water circulation.

\section{GENERAL MINERALOGIC AND GEOCHEMICAL STRATIGRAPHY}

Based on the proximity of Sites 535 and 540 together with the complementary nature of the sedimentary columns recovered, we have attempted to establish a miner- 


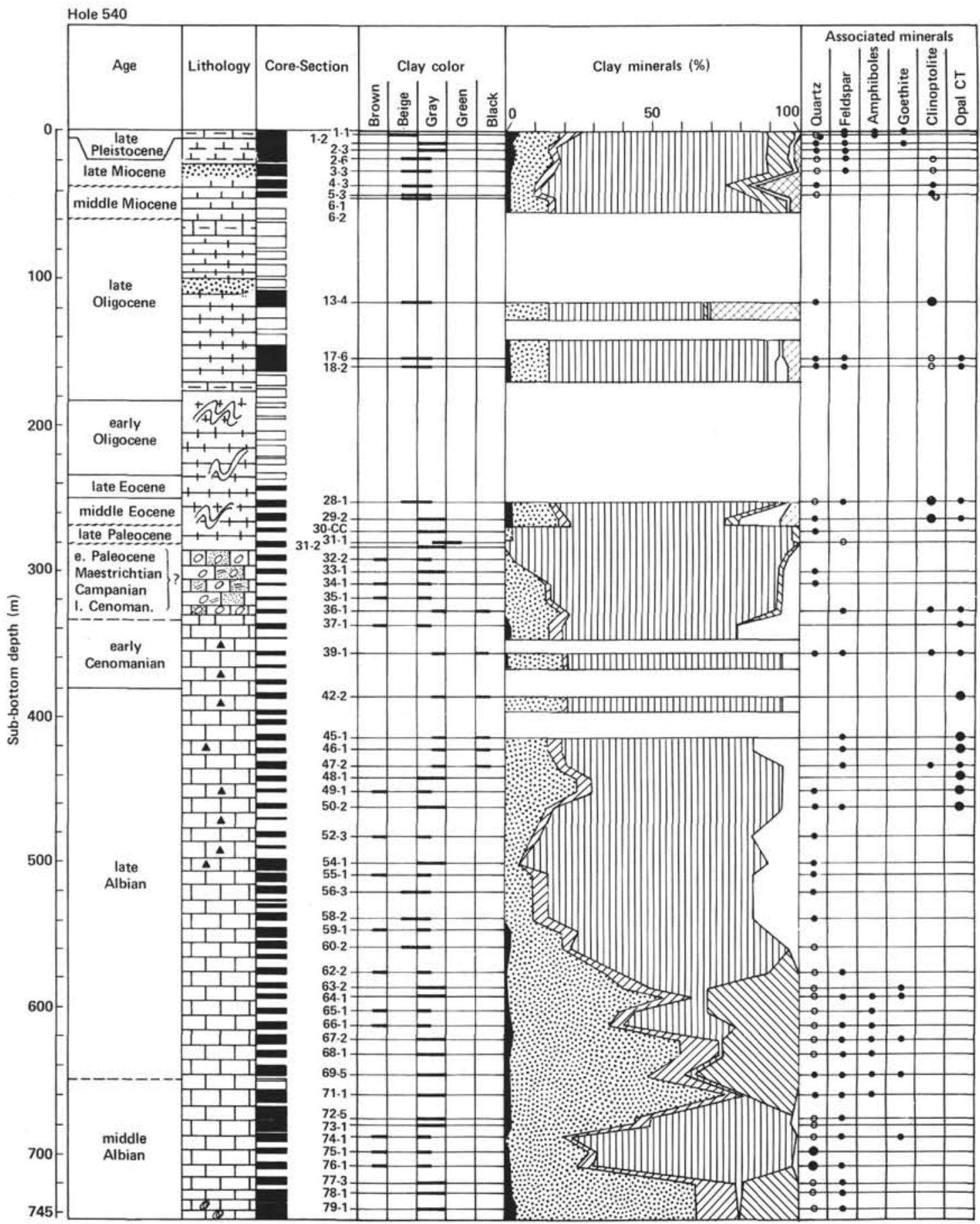

Figure 5. (Continued)

alogic and geochemical stratigraphic summary. Such a reconstruction, including various hiatuses especially during the Late Cretaceous and early Paleogene, is presented on Figure 9 and shows the following main zones:

Berriasian to Aptian. Three major illite stages, interpreted as consequences of continental morphologic rejuvenation to spreading stages in the Gulf of Mexico, interrupt a smectite-rich and typically detrital sedimentation, probably linked to a general context of tectonic relaxation and subarid climate. The illite stages correspond to temporary bottom oxidations, which delineate an Early Cretaceous alternation of oxidized and reduced conditions. Above the upper Hauterivian, the geochemical environment becomes more siliceous and magnesian.

Albian, Cenomanian. The mineralogic and geochemical instability, suggesting a tectonic activity on land masses surrounding the Gulf of Mexico, increased during the early-middle Albian, a condition that did not occur in the open northwestern Atlantic during the same period (Chamley et al., in press). The relative proximity to evaporitic zones at Site 540 appears to be expressed by higher $\mathrm{Si}, \mathrm{Mg}, \mathrm{Ca}$, and $\mathrm{Na}$ contents. On the other hand, the late Aptian to early Cenomanian period was 


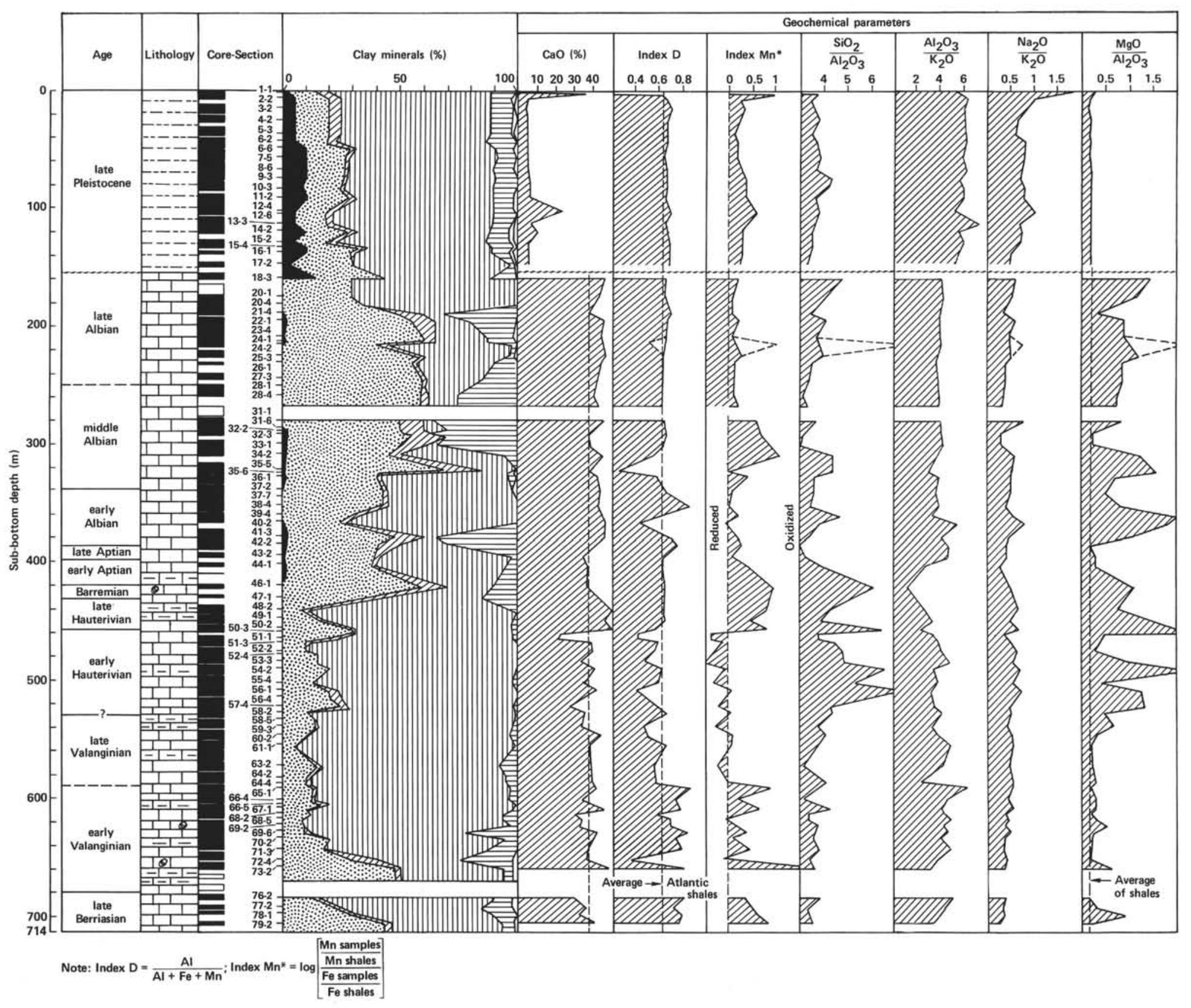

Figure 6. Hole 535, comparison of geochemical and mineralogic data. See Figure 2 for symbols. 


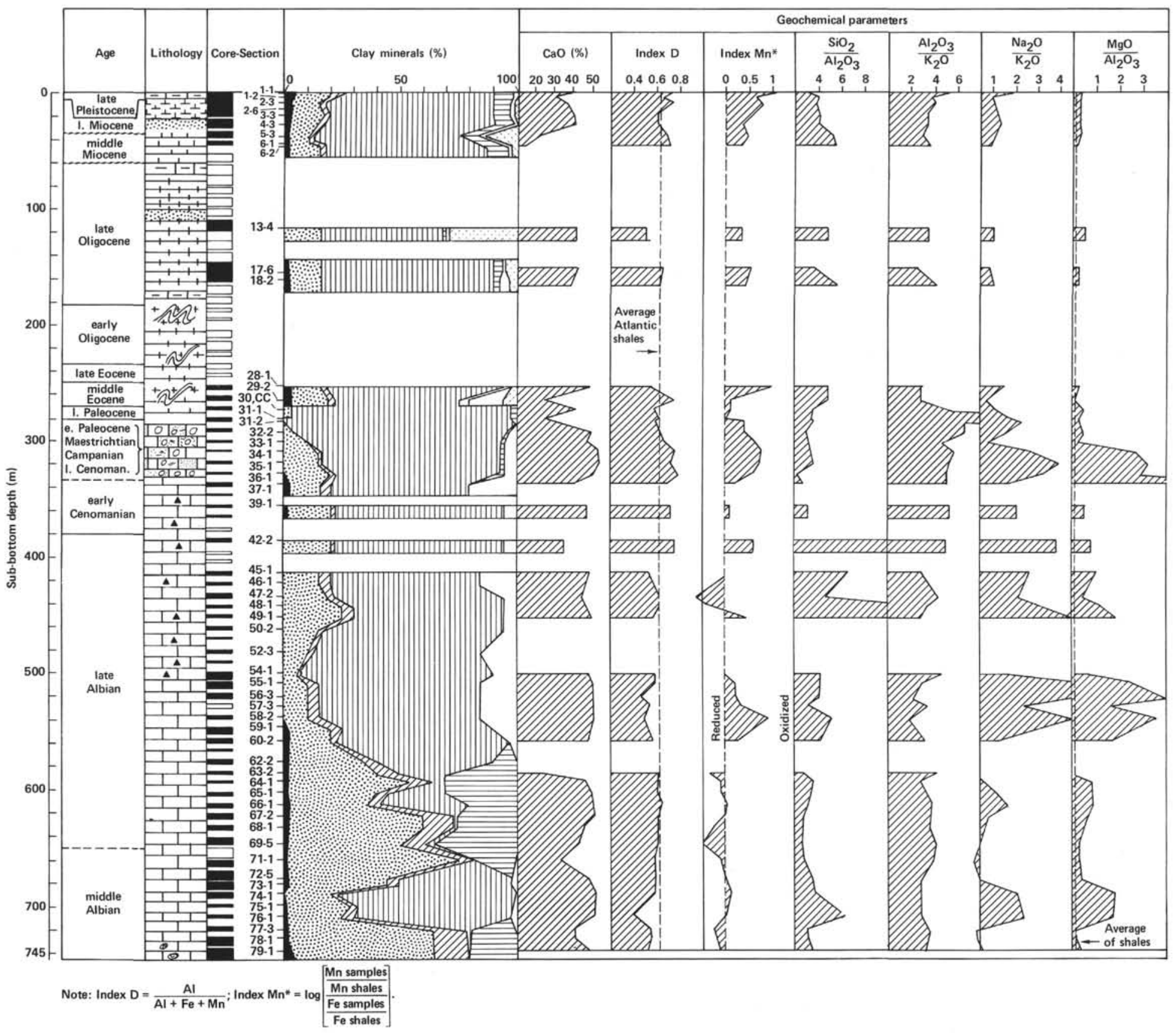

Figure 7. Hole 540, comparison of geochemical and mineralogic data. See Figure 2 for symbols. 


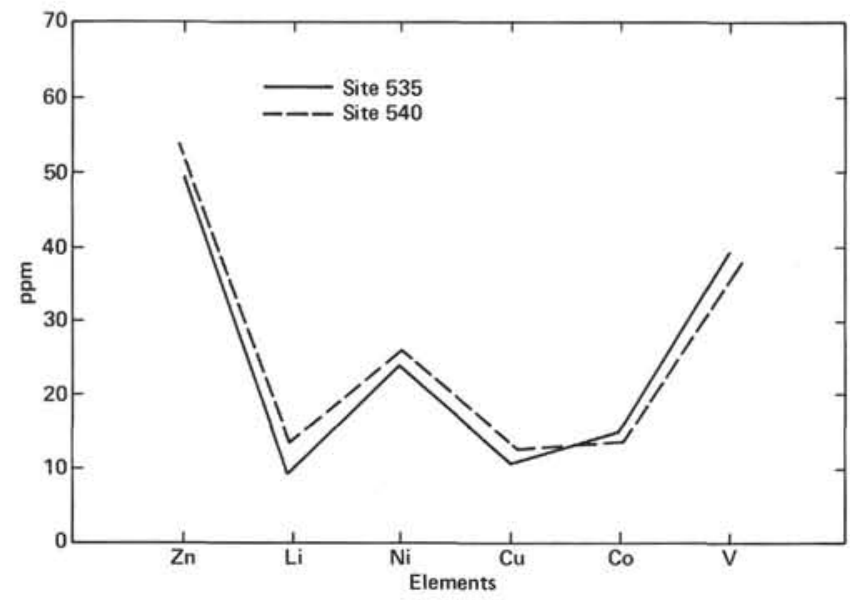

Figure 8. Sites 535 and 540, average distribution of trace elements in middle-late Albian sediments.

characterized by a homogeneous smectitic sedimentation, the presence of palygorskite (also appearing at Site 538 ), increased amounts of $\mathrm{Si}$ and $\mathrm{Mg}$, and oxidized conditions. These data, indicative of rather stable continental margins and of pedogenic development under a hot and subarid climate, correspond to those identified at the same period in the open Atlantic Ocean (Chamley, 1979; Chamley et al., in press; Debrabant et al., 1979).

Late Cretaceous. The Late Cretaceous mineralogically was similar to the stable and warm late Albian-Cenomanian and differed from the open Atlantic, where a major tectonic instability occurred (Chamley and Robert, 1979). Insufficient sediment recovery during drilling could cause this discrepancy. According to inorganic geochemical studies, the sediment became more aluminous-sodic and similar to that of the open Atlantic Ocean, whereas fluctuations occurred in the oxidation-reduction potential, suggesting variations in the deep-water circulation regime.

Cenozoic. Some mineralogic and geochemical characteristics correspond to general events encountered in the Atlantic Ocean (Chamley, 1979; Debrabant and Foulon, 1979): Paleogene development of fibrous clays with associated opal CT and clinoptilolite, reflecting the development of perimarine basins and the increased importance of the silica budget; late Cenozoic augmentation of minerals reworked directly from continental rocks and upstream soils, evoking the worldwide cooling and the erosion increase. Other characteristics seem to be restricted to the eastern Gulf of Mexico: the possible tectonic influence during the Eocene reworking of fibrous clays, accompanied by an increase of the detrital character (Index D) of the potassium and the free silica and by a poorly oxidized environment; the Oligocene supply of sepiolite and Miocene supply of palygorskite, from perimarine basins developed in the Southeastern U.S. (Weaver and Beck, 1977); the predominant influence of the Mississippi River on the clay sedimentation during the late Cenozoic; and the possible volcanic influence expressed by temporary $\mathrm{Si}$ and $\mathrm{Fe}$ increases during the Eocenemiddle Eocene interval.

\section{Albian Mineralogic Stratigraphy}

The Albian, chiefly represented by its lower and middle part at Site 535 and by its middle and upper part at Site 540 , shows a strong variability of clay assemblages (Fig. 9). The alternation of illite/kaolinite-rich and smectite-rich levels and the local presence of palygorskite can be used to define mineralogic stratigraphic markers. Therefore the successive mineralogic changes occurring at both sites can be tentatively compared, in order to propose an indirect tool of stratigraphic correlation. An attempt at such correlation is shown on Figure 10, and an imbrication of mineralogic successions recovered in both drill sites is proposed. On this figure, the uppermost Albian levels of Site 535 (Core 535-20 to Section 535-24-1) correlate with Site 540 (Cores 62 to 64), and the lowermost Albian levels of Site 540 (Cores 77 to 79) correlate with Section 535-35-5. Such a tentative correlation could help compare the two sites, whose lithologic differences preclude a direct comparison (site chapter, Sites 535, 539, and 540, this volume). A slight but systematic difference occurs in the Albian mineralogic compositions at these two sites. Smectites are somewhat more abundant at Site 535 than at Site 540 in a given period, especially during the time intervals marked by noticeable illite and kaolinite supply (Fig. 9). The cause could be the higher dispersion potential of smectites in seawater, compared to illite and kaolinite, giving way to a classic differential settling at increased distance from land masses (Whitehouse et al., 1960; Gibbs, 1977). This suggests that at least during the Albian the main detrital sources of clay materials were located in the east-Northeast of the Gulf of Mexico, in the direction of the present Florida.

\section{CORRELATIONS BETWEEN LITHOLOGY, CLAY MINERALOGY, AND INORGANIC GEOCHEMISTRY}

The boundaries between the main lithologic units correspond poorly or not at all to the boundaries between the main mineralogic zones (see above and Fig. 5). In a given lithologic unit, as for instance the Albian limestones of Sites 535 (Cores 18 to 42) and 540 (Cores 53 to $76)$, the clay mineralogy strongly changes with time, independently of the rock facies. This general independence between the lithostratigraphy and the clay stratigraphy, together with the lack of noticeable relationships between the clay mineralogy and the depth of burial, the local presence of volcanic glass, siliceous accumulations or organic matter, and the average grain size, points to the absence or weakness of argillaceous diagenetic manifestations. The same result occurs for most of Mesozoic and Cenozoic series drilled in the Atlantic Ocean, and only local, temporary, or minor diagenetic processes appear to exist (Chamley, 1979, 1981).

A similar independence between lithology and clay mineralogy appears when data are compared in a more precise manner. An attempt has been made for selected samples of Sites 535 and 540 Albian limestones, marly limestones and marls, alternating or not (Fig. 11). Sometimes a close correspondence occurs, sometimes a total lack of correspondence, between lithology and clay 


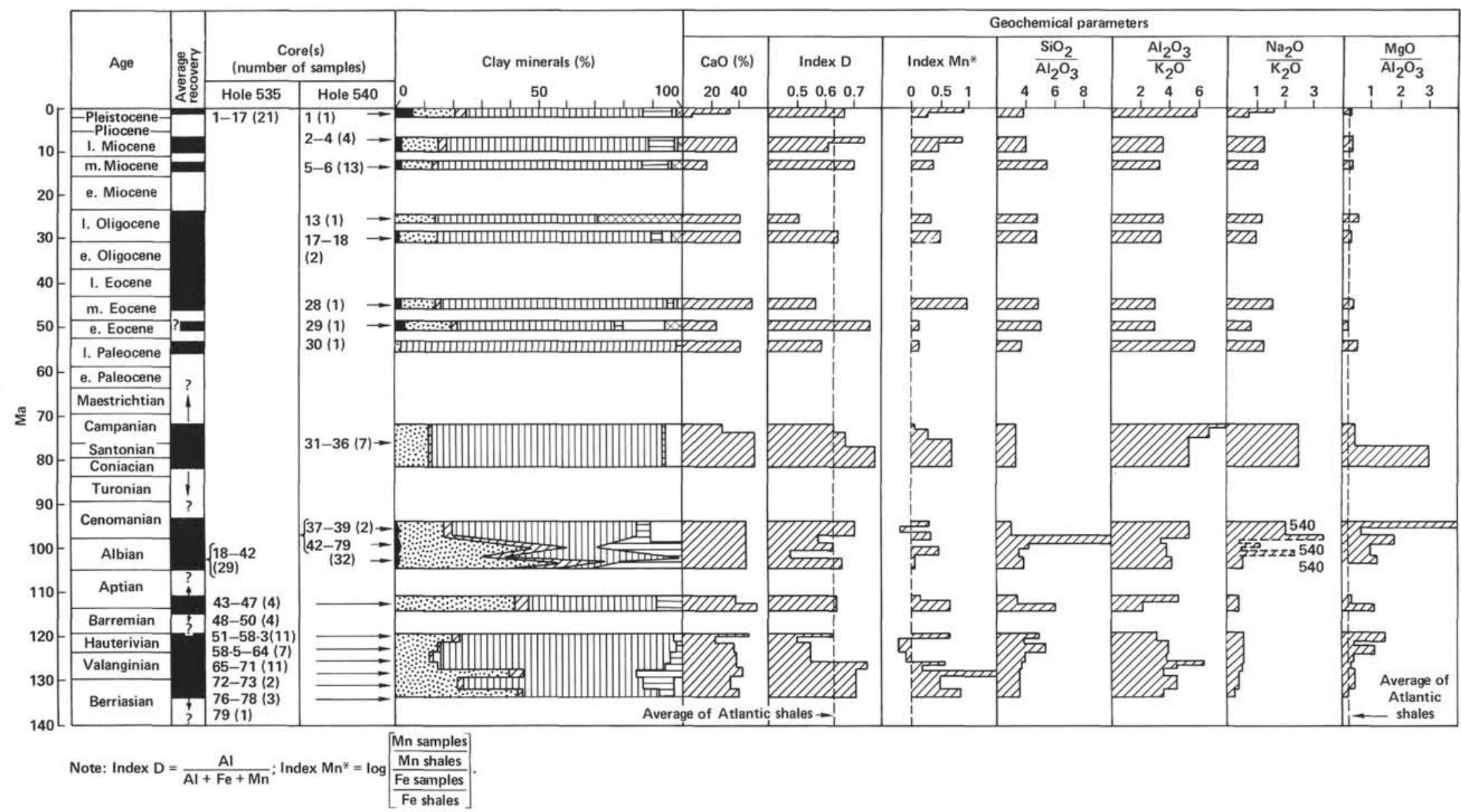

Figure 9. Sites 535 and 540 , comparison of geochemical and mineralogic data. See Figure 2 for clay mineralogy symbols. 


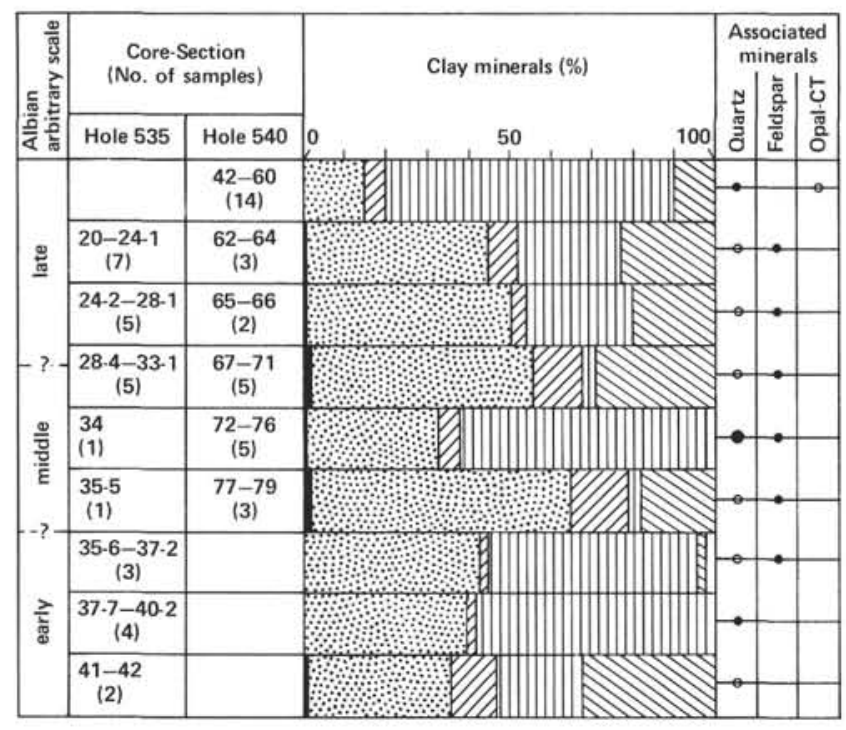

Figure 10. Tentative Albian correlations between Sites 535 and 540 from clay mineralogic data. See Figure 2 for mineralogy symbols.

mineralogy. If relationships do exist between both parameters, they only should occur on a still more detailed scale than those considered here (e.g., Cotillon et al., 1980).

General relationships exist between the lithology and the distribution of major elements in the bulk geochemistry (especially $\mathrm{CaO}$ and $\mathrm{SiO}_{2}$ ). But variable behaviors appear when specific geochemical parameters are considered, compared to the general lithology expressed by the $\mathrm{CaO}$ content. For instance, Index $\mathrm{D}$ generally varies symmetrically with $\mathrm{CaO}$ content (i.e., late Albian, Cenomanian of Sites 535 and 540), because of opposite contributions of terrigenous supply (chiefly marked by $\mathrm{Al}$ ) and of marine carbonates. But sometimes $\mathrm{D}$ parallels (Berriasian, Hauterivian of Site 535) or does not depend on (middle-late Albian) the lithology, because of the variable intensity of carbonate diagenetic processes (dissolution or not in porous chalks, local precipitation of dolomite from pore waters).

Index $\mathrm{Mn}^{*}$ generally does not depend on the lithology and $\mathrm{CaO}$ contents, and chiefly reflects oxidized bottom conditions and the precipitation of transition metals. But sometimes $\mathrm{Mn}^{*}$ values parallel those of $\mathrm{CaO}$ (e.g., in Pleistocene sediments) because of isomorphic similarities of $\mathrm{Mn}^{2+}$ and $\mathrm{Ca}^{2+}$, absence of diagenetic carbonate recrystallization, and presence of oxidized depositional environments. A similar parallelism sometimes occurs under reducing conditions (Hauterivian of Site 535), when $\mathrm{Mn}$ is incorporated in carbonate minerals (rhodochrosite, manganocalcite).

The ratio $\mathrm{SiO}_{2} / \mathrm{Al}_{2} \mathrm{O}_{3}$ commonly reflects the abundance of clay minerals and varies inversely with $\mathrm{CaO}$, but also depends locally on the presence of detrital, biogenic, or diagenetic-free silica. Its fluctuations usually parallel those of $\mathrm{MgO} / \mathrm{Al}_{2} \mathrm{O}_{3}$ and sometimes $\mathrm{Na}_{2} \mathrm{O} / \mathrm{K}_{2} \mathrm{O}$ (Albian), which frequently express the abundance of smectites or fibrous clays. The parallelism observed tempo-
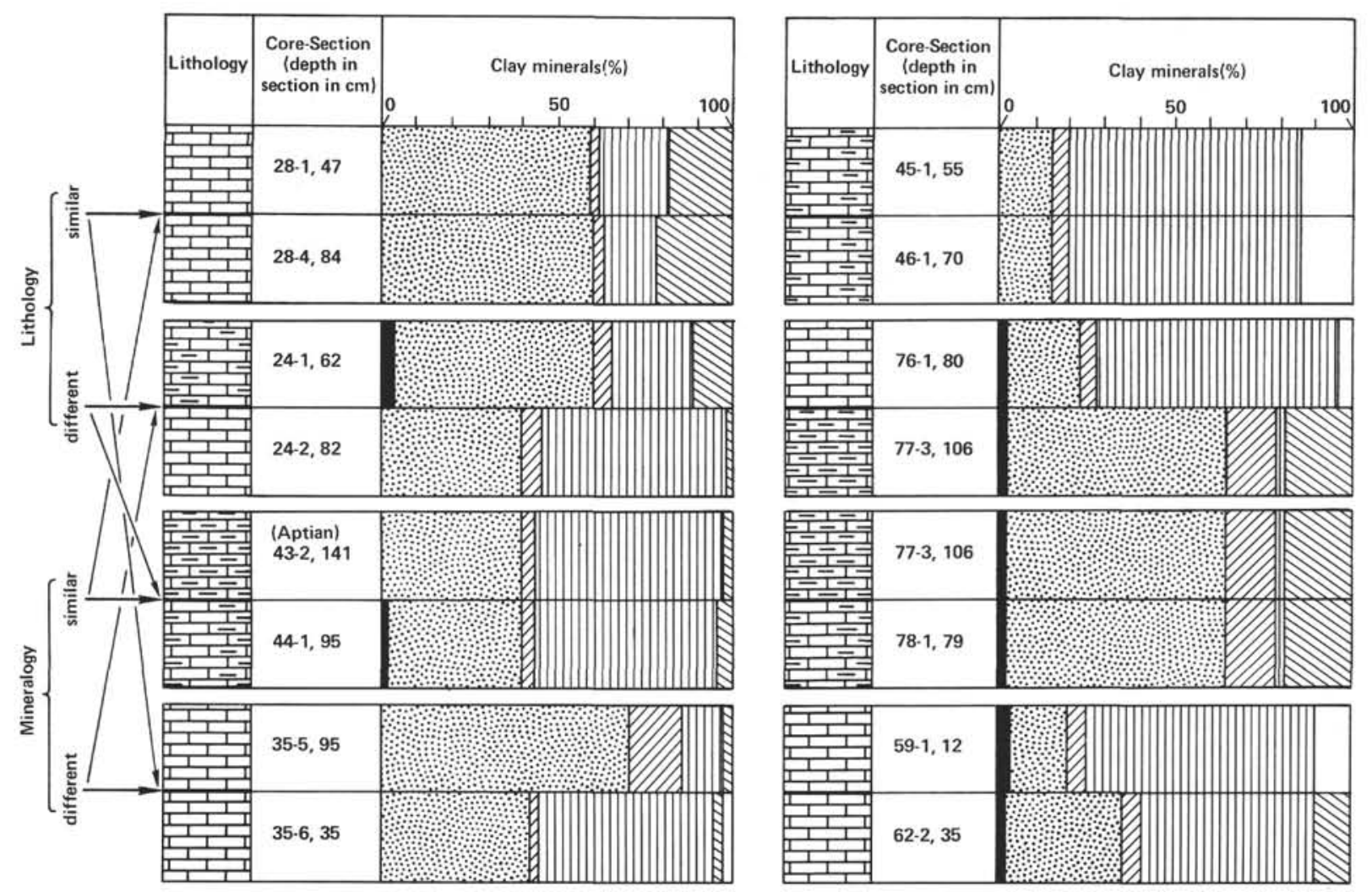

Figure 11. Sites 535 and 540, relationships between lithology and clay mineralogy from Albian samples. See Figure 2 for symbols. 
rarily between these ratios and $\mathrm{CaO}$ (Albian) probably results from the wide dispersion potential of smectites, deposited under pelagic conditions in the same way as biogenic carbonates. Locally, during the Cenozoic, $\mathrm{MgO}$ / $\mathrm{Al}_{2} \mathrm{O}_{3}$ does not parallel other parameter fluctuations, which express the fibrous clay input or volcanic influences (Debrabant and Foulon, 1979; Bloch, 1981).

\section{Carbonate Diagenesis}

During the precipitation of biogenic carbonates, the strontium is trapped in mineral structures, and its abundance roughly parallels the calcium carbonate abundance (Müller and Friedman, 1968; Kinsman, 1969). During the carbonate diagenesis, $\mathrm{Sr}$ tends to decrease, because of crystalline reorganizations and chemical exchanges between minerals and pore waters. The relation $\mathrm{Sr}=\mathrm{f}(\mathrm{CaO})$ disappears with time. The construction of regression lines allows precise determination of the rate of decrease of $\mathrm{Sr}$ and therefore of carbonate diagenesis during the Cenozoic (Fig. 12). The Pleistocene sediments of Sites 535 and 540 show the following relation:

$$
\mathrm{r}=1 ; \mathrm{Sr}=39.5 \mathrm{CaO}-20 .
$$

This points to the mutual precipitation of $\mathrm{CaCO}_{3}$ and $\mathrm{Sr}$ and to the lack of appreciable diagenetic evolution. A similar relation occurs in the Atlantic Ocean during the Pliocene-Pleistocene, especially in the northwestern basins (i.e., Site 101 of Leg 11: $\mathrm{r}=0.99 ; \mathrm{Sr}=40.5 \mathrm{CaO}$ +83 ). Note that at the top of Sites 535 and 540 , some samples are highly enriched in $\mathrm{Sr}$, as a result of the presence of the aragonitic shells of pteropods.

As far as the Oligocene-Miocene is concerned (Site 540 ), $\mathrm{Sr}$ and $\mathrm{CaO}$ remain correlated in a linear manner, but the regression line significantly differs from the Pleistocene one:

$$
\mathrm{r}=1 ; \mathrm{Sr}=21.9 \mathrm{CaO}+307 .
$$

The excess of $\mathrm{Sr}(307 \mathrm{ppm})$ calculated when carbonates are absent could correspond to a $\mathrm{Sr}$ supply by terrige-

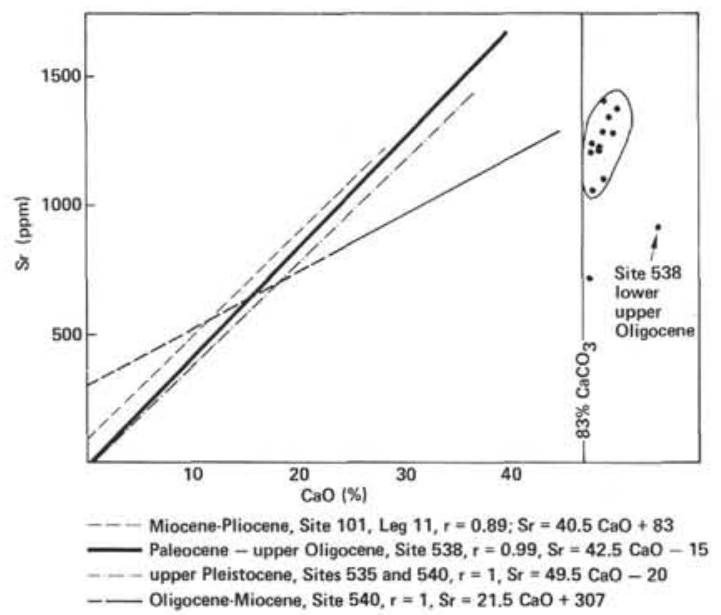

Figure 12. DSDP Legs 11 and 77, Cenozoic relationships between $\mathrm{Sr}$ and $\mathrm{CaO}$. nous matter and does not agree with the variability of the clay minerals deposited with time. Probably Sr released during carbonate diagenesis was trapped by the abundant clay minerals and therefore preserved from expulsion into the pore waters.

The Paleocene to late Oligocene sediments of Site 538 (Catoche Knoll) show a regression line similar to that of Pleistocene sediments of Sites 535-540.

$$
\mathrm{r}=0.99 ; \mathrm{Sr}=42.5 \mathrm{CaO}-15,
$$

indicating weak and progressive diagenetic changes. The cause of that similarity in $\mathrm{Sr}$ behavior, in spite of the difference of ages, probably lies in the fairly low sedimentation rate at Site 538, diminishing the burial influences, and in trapping $\mathrm{Sr}$ clay minerals. Indirect evidence for the latter cause comes from the Oligocene sediments of Site 538; poorer in clay (less than 17\%) than the whole Paleocene-Oligocene series (more than $25 \%$ ), these sediments show a nonlinear $\mathrm{Sr} / \mathrm{CaO}$ relation and probably reflect the elimination of $\mathrm{Sr}$ in pore waters.

As a consequence, the Cenozoic carbonate diagenesis appears to be expressed in various manners by the $\mathrm{Sr} /$ $\mathrm{CaO}$ relationships. When diagenesis is very low (Pleistocene in most cases, but also older sediments when the burial effects are low and pore-water circulations precluded by abundant clay), the linearity of both chemical elements is roughly maintained. The increased action of diagenesis, particularly significant at depths greater than $150-200 \mathrm{~m}$ below the mudline, is expressed by a progressive decrease of the slopes of the regression lines $[\mathrm{Sr}=$ $\mathrm{f}(\mathrm{CaO})]$, if the porosity is high enough to allow the $\mathrm{Sr}$ elimination in pore waters. If abundant clay materials are present, they are able to trap most of the $\mathrm{Sr}$ released and thus resist the effects of burial diagenesis. Later on the relation $\mathrm{Sr}=\mathrm{f}(\mathrm{CaO})$ disappears, when $\mathrm{Sr}$ strongly decreases. A correspondence can reappear in older sediments, when all the calcium carbonate is stabilized as calcite, and when the pore-water circulations are stopped after definitive recrystallization.

\section{CONCLUSION}

The Mesozoic and Cenozoic sediments of the western Florida Straits, sparsely sampled at Sites 536, 537, and 538 , more densely at Sites 535 and 540, and nearly unaffected by the argillaceous diagenesis and variously affected by the calcareous diagenesis. The relation $\mathrm{Sr}=$ $\mathrm{f}(\mathrm{CaO})$ appears to be a good indicator of various influences on carbonates: depth of burial, age, porosity, and recrystallization.

The transition of continental to marine environments close to the lowermost Cretaceous is clearly expressed north of the Campeche Escarpment (Site 537) by an evaporitic clay stage. During the Cretaceous and the Cenozoic, a mineralogic and geochemical stratigraphy is established, which allows us to propose general correlations between Sites 535 and 540 (south of the western Florida Escarpment) and also specific correlations about the Albian stage.

The lack of relationships at different scales between the lithology, the petrography, the clay mineralogy, and 
some geochemical indices shows the importance of detrital supply in inorganic sedimentation and allows paleoenvironmental interpretations. Most of the Cretaceous and Paleogene is characterized by a warm and humidity-contrasted climate, favoring the genesis of smectites in continental soils developed in gently sloped areas. Such a climatic expression was permitted by the predominance of a tectonic stability on the margins of the Gulf of Mexico. Temporary tectonic destabilizations occurred chiefly until the middle Albian and are marked by a mineralogic diversification, the reworking of both geologic and pedogenic minerals, and the interruption of reduced conditions by oxygenated events. The development of confined perimarine basins, marked by the genesis of fibrous magnesian clays, occurred during the Berriasian(?), the late Albian, the Eocene, and the Oligocene, and until the Miocene.

Volcanic influences affect the clay mineralogy very little, except probably during the latest Cretaceous when $\mathrm{Li}$-smectites and $\mathrm{Fe}-\mathrm{Mn}$ concretions developed at the time that widespread volcanism occurred in Cuba and the Greater Antilles. Other volcanic influences are probably expressed by the geochemistry, especially for the early Paleogene. In a general way, the chemical character of the sedimentation appears more magnesian in the Gulf of Mexico than in the open Atlantic Ocean, at least until the Eocene, pointing to the persistence of rather confined conditions of deposit.

The sources of inorganic materials (indicated by differential settling processes, the abundance of fibrous clays, and the average composition of mineral assemblages) appear to have been chiefly located in the eastnortheast of the Gulf of Mexico, from the Early Cretaceous until the Neogene. During the Pleistocene, the output of Mississippi River became predominant in the whole area investigated.

\section{ACKNOWLEDGMENTS}

We are greatly indebted to the National Science Foundation, to Drs. R. Buffler, N. Schlager, and P. Cotillon and other shipboard scientists for authorizing the study of Leg 77 DSDP materials and doing the sampling. B. Biju-Duval, P. Cotillon, and K. Pisciotto pertinently reviewed the manuscript. The technical work was done in Lille University with the help of M. Bocquet, J. Carpentier, A. Deremaux, F. Dujardin, and P. Récourt. The financial support was given by Centre National de la Recherche Scientifique (France), through Grant YP 3 1981980 of Action Thématique Programmée, IPOD.

\section{REFERENCES}

Bloch, S., 1981. Antipathetic Mg-Mn relationship in basal metalliferous sediments. Chem. Geol., 33:101-113.

Buffler, R. T., Shaub, F. J., Huerta, R., Ibrahim, A. B. K., and Watkins, S. S., 1981. A model for the early evolution of the Gulf of Mexico Basin. Oceanol. Acta, C3:129-136.

Chamley, H., 1971. Recherches sur la sédimentation argileuse en mèditerraneé. Mem. Sci. Geol., 35.

Chamley, H., 1979. North Atlantic clay sedimentation and paleoenvironment since the Late Jurassic. In Talwani, M., Hay, W. W., Ryan, W. B. F. (Eds.), Deep Drilling Results in the Atlantic Ocean: Continental Margins and Paleoenvironment: Washington (Am. Geophys. Union), Maurice Ewing Series, 3:342-361.

1981. Long-term trends in clay deposition in the ocean. Oceanol. Acta, 4:105-110.
Chamley, H., Debrabant, P., Candillier, A.-M., and Foulon, J., in press. Clay mineralogical and inorganic geochemical stratigraphy of Blake Bahama Basin since the Callovian (Site 534, Leg 76 DSDP). In Sheridan, R. E., Gradstein, F. M., et al., Init. Repts. DSDP, 76: Washington (U.S. Govt. Printing Office).

Chamley, H., Debrabant, P., Foulon, J., Giroud d'Argoud, G., Latouche, C., Maillet, N., Maillot, H., and Sommer, F., 1979. Mineralogy and geochemistry of Cretaceous and Cenozoic Atlantic sediments off the Iberian Peninsula (Site 398, DSDP Leg 47B). In Sibuet, J.-C., Ryan, W. B. F., et al., Init. Repts. DSDP, 47, Pt. 2: Washington (U.S. Govt. Printing Office), 429-449.

Chamley, H., and Kennett, J.-P., 1976. Argiles détritiques, Foraminifères planctoniques et paléoclimats, dans des sédiments quaternaires du Golfe du Mexique. C. R. Acad. Sci. Paris, 282D:415-418.

Chamley, H., and Robert, C., 1979. Late Cretaceous to early Paleogene environmental evolution expressed by the Atlantic clay sedimentation. In Christensen, W. K., and Birkelung, T. (Eds.), Cretac.-Tertiary Boundary Events Symp., Proc., 2:71-77.

Cotillon, P., Ferry, S., Gaillard, C., Jautee, E., Latreille, G., and Rio, M., 1980. Fluctuation des paramètres du milieu marin dans le domaine vocontien (France sud-est au Crétacé inférieur), mise en évidence par l'étude des formations marno-calcaires alternantes. Bull. Soc. Geol. France, XXII(7):735-744.

Debrabant, P., Chamley, H., Foulon, J., and Maillot, H., 1979.Mineralogy and geochemistry of upper Cretaceous and Cenozoic sediments from North Biscaye Bay and Rockall Plateau (eastern North Atlantic), DSDP Leg 48. In Montadert, L., Roberts, D. G., et al., Init. Repts. DSDP, 48: Washington (U.S. Govt. Printing Office), 703-725.

Debrabant, P., and Foulon, J., 1979. Expression géochimique des variations du paléoenvironnement depuis le Jurassique supérieur sur les marges nord-atlantiques. Oceanol. Acta, 2:469-476.

Gibbs, R. J., 1977. Clay mineral segregation in the marine environment. J. Sed. Petrol., 47:237-243.

Grim, R. E., and Johns, W. D., 1954. Clay mineral investigations of sediments in the northern Gulf of Mexico. Clays Clay Min., 2: 81-103.

Johns, W. D., and Grim, R. E., 1958. Clay mineral composition of recent sediments from the Mississippi River delta. J. Sed. Petrol., 28: 186-199.

Kinsman, D. J. J., 1969. Interpretation of $\mathrm{Sr}^{2+}$ concentrations in carbonate minerals and rocks. J. Sed. Petrol., 39:486-508.

Maillot, H., and Robert, C., 1980. Minéralogie et géochimie des sédiments crétacés et cénozoïques dans l'Océan Atlantique Sud (marge africaine, dorsale médio-atlantique). Bull. Soc. Geol. France, XXII(7):777-788.

Mélières, F., 1967. Recherches sur les sédiments marins actuels du Golfe du Mexique [Thèse]. Paris.

Millot, G., 1964. Géologie des Argiles: Paris (Masson).

Müller, G., and Friedman, G. M., 1968. Recent Developments in Carbonate Sedimentology in Central Europe: Berlin, Heidelberg, New York (Springer-Verlag).

Pinsak, A. P., and Murray, H. H., 1960. Regional clay mineral patterns in the Gulf of Mexico. Clays Clay Min., 7:178-184.

van Andel, T. H., and Poale, D. H., 1960. Source of recent sediment of the north west Florida coast. J. Sediment. Petrol., 29:555-563.

Weaver, C. E., and Beck, K. C., 1977. Miocene of the SE United States: a model for chemical sedimentation in a peri-marine environment. Sediment. Geol., 17:1-234.

Whitehouse, V. G., Jeffrey, L. M., and Debrecht, J. D., 1960. Differential settling tendencies of clay minerals in saline waters. Clays Clay Min., 7:1-80.

Zemmels, I., and Cook, H. E., 1973. X-ray mineralogy studies of Leg 10 cores in the Gulf of Mexico. In Worzel, J. L., Bryant, W., et al., Init. Repts. DSDP, 10: Washington (U.S. Govt. Printing Office), 337-373.

Date of Initial Receipt: July 27, 1982

Date of Acceptance: September 27, 1982 
APPENDIX

Bulk Inorganic Chemistry, Leg 77

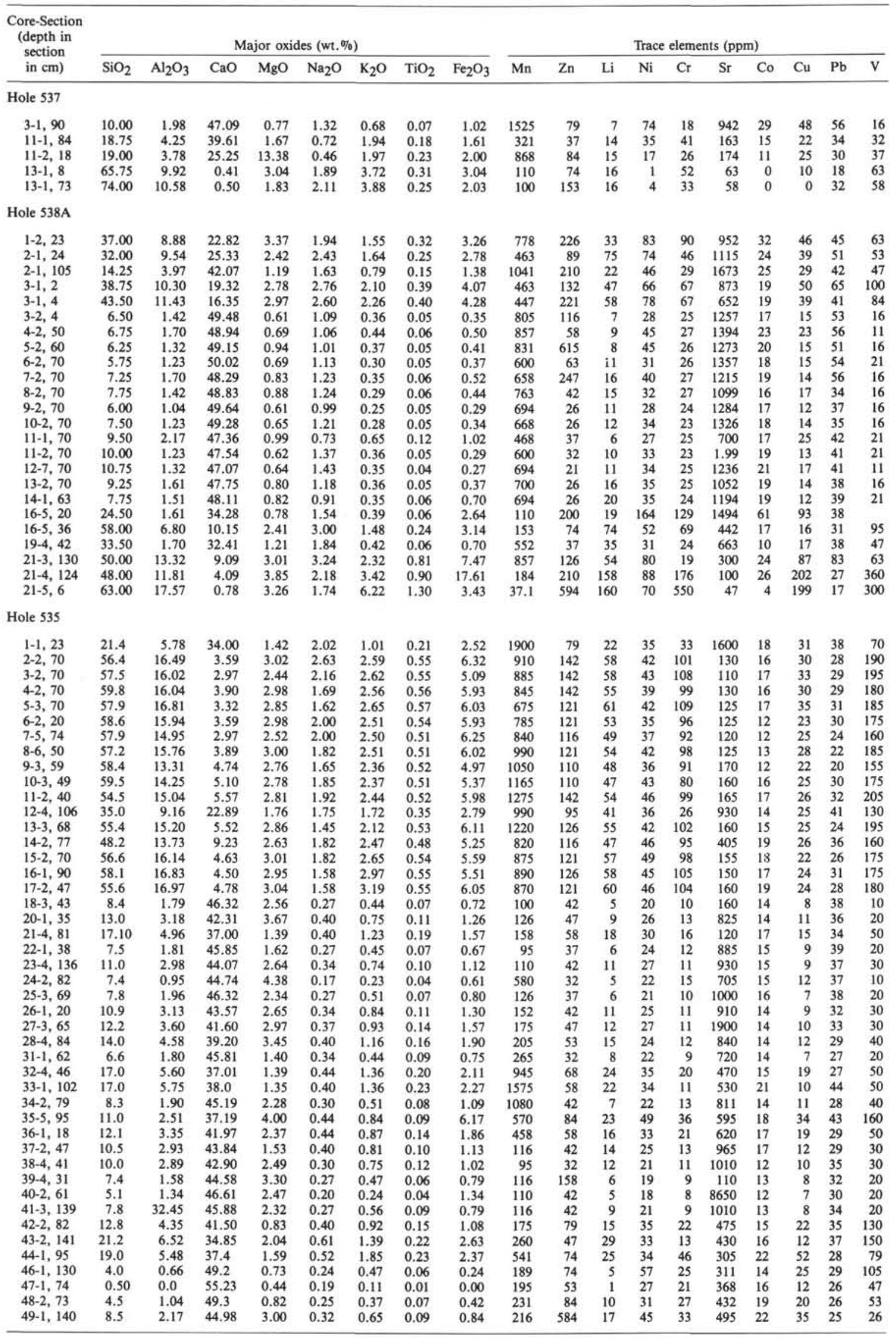


Appendix. (Continued).

\begin{tabular}{|c|c|c|c|c|c|c|c|c|c|c|c|c|c|c|c|}
\hline $\begin{array}{l}\text { Core-Section } \\
\text { (depth in } \\
\text { section }\end{array}$ & & & & $\mathrm{r}$ & es (wt.\% & & & & & & & Trace & elemen & nts (ppr & \\
\hline & $\mathrm{SiO}_{2}$ & $\mathrm{Al}_{2} \mathrm{O}_{3}$ & $\mathrm{CaO}$ & $\mathrm{MgO}$ & $\mathrm{Na}_{2} \mathrm{O}$ & $\mathrm{K}_{2} \mathrm{O}$ & $\mathrm{TiO}_{2}$ & $\mathrm{Fe}_{2} \mathrm{O}_{3}$ & $\mathrm{Mn}$ & $\mathrm{Zn}$ & $\mathrm{Li}$ & $\mathrm{Ni}$ & $\mathrm{Cr}$ & $\mathrm{Sr}$ & Co \\
\hline Hole 535 (C & & & & & & & & & & & & & & & \\
\hline $50-2,70$ & 5.0 & 0.76 & 49.04 & 2.46 & 0.22 & 0.32 & 0.04 & 0.41 & 252 & 63 & 7 & 26 & 27 & 574 & 14 \\
\hline $50-3,27$ & 26.50 & 7.09 & 22.23 & 3.50 & 0.79 & 2.08 & 0.26 & 7.39 & 274 & 210 & 48 & 74 & 92 & 421 & 20 \\
\hline $51-1,147$ & 27.50 & 7.27 & 21.38 & 3.40 & 0.71 & 1.91 & 0.27 & 7.61 & 274 & 174 & 49 & 79 & 98 & 426 & 19 \\
\hline $51-3,7$ & 16 & 3.59 & 38.66 & 1.56 & 0.50 & 0.92 & 0.17 & 1.78 & 121 & 84 & 19 & 42 & 50 & 437 & 16 \\
\hline $52-2,20$ & 15.5 & 3.21 & 39.33 & 0.91 & 0.50 & 0.77 & 0.16 & 1.92 & 89 & 84 & 16 & 41 & 49 & 558 & 16 \\
\hline $53-3,16$ & 19.0 & 3.87 & 33.43 & 4.12 & 0.44 & 0.79 & 0.16 & 3.33 & 89 & 79 & 17 & 38 & 47 & 626 & 15 \\
\hline $54-2,141$ & 13 & 1.98 & 40.69 & 4.23 & 0.41 & 0.58 & 0.08 & 0.88 & 68 & 58 & 9 & 40 & 43 & 711 & 13 \\
\hline $55-4,64$ & 22.5 & 4.16 & 35.06 & 1.84 & 0.61 & 1.10 & 0.18 & 2.16 & 89 & 132 & 16 & 44 & 65 & 668 & 14 \\
\hline $56-1,90$ & 12.5 & 1.70 & 41.10 & 2.11 & 0.40 & 0.53 & 0.08 & 1.86 & 189 & 68 & 9 & 40 & 33 & 758 & 18 \\
\hline $57-4,56$ & 22 & 5.10 & 27.47 & 6.73 & 0.73 & 1.48 & 0.23 & 2.68 & 142 & 84 & 18 & 56 & 93 & 721 & 14 \\
\hline $58-2,21$ & 19.5 & 4.44 & 36.49 & 2.17 & 0.55 & 1.06 & 0.19 & 1.71 & 174 & 95 & 16 & 43 & 51 & 842 & 17 \\
\hline $59-3,78$ & 18 & 4.72 & 33.36 & 3.27 & 0.64 & 1.39 & 0.22 & 3.96 & 179 & 153 & 22 & 93 & 84 & 663 & 19 \\
\hline $60-2,0$ & 12 & 2.93 & 44.08 & 0.96 & 0.43 & 0.75 & 0.14 & 2.19 & 247 & 47 & 12 & 31 & 38 & 795 & 18 \\
\hline $61-1,98$ & 20 & 5.29 & 38.18 & 1.21 & 0.63 & 1.08 & 0.22 & 2. & 216 & 63 & 17 & 35 & 47 & 768 & 18 \\
\hline $63-2,30$ & 12 & 3.78 & 38.95 & 0.95 & 0.43 & 0.90 & 0.14 & 2. & 121 & 100 & 12 & 85 & 66 & 821 & 14 \\
\hline $64-4,61$ & 15 & 3.59 & 39.19 & 1.17 & 0.82 & 1.53 & 0.28 & 1.96 & 163 & 150 & 21 & 102 & 79 & 658 & 12 \\
\hline $65-1,5$ & 24 & 6.33 & 41.02 & 1.25 & 0.53 & 0.98 & 0.15 & 0.68 & 470 & 215 & 13 & 69 & 46 & 832 & 13 \\
\hline $66-4,8$ & 8.19 & 6.05 & 33.67 & 1.97 & 0.60 & 1.32 & 0.27 & 1.61 & 211 & 47 & 18 & 51 & 54 & 816 & 19 \\
\hline $67-1,24$ & 12.5 & 2.93 & 45.67 & 0.92 & 0.39 & 0.71 & 0.13 & 0.58 & 242 & 42 & 10 & 33 & 38 & 947 & 15 \\
\hline $68-2,110$ & 23.5 & 6.90 & 29.91 & 1.36 & 0.61 & 1.61 & 0.32 & 3.68 & 663 & 61 & 28 & 66 & 55 & 716 & 43 \\
\hline $68-5,101$ & 22.5 & 6.61 & 33.83 & 1.94 & 0.62 & 1.35 & 0.26 & 2. & 168 & 47 & 35 & 50 & 52 & 574 & 22 \\
\hline $69-2,1$ & 23 & 6.05 & 32.41 & 3.71 & 0.57 & 1.45 & 0.27 & 1.5 & 253 & 45 & 34 & 42 & 50 & 595 & 19 \\
\hline $69-6,71$ & 15.5 & 4.25 & 42.79 & 1.11 & 0.46 & 0.91 & 0.16 & 0.64 & 147 & 47 & 21 & 42 & 40 & 732 & 15 \\
\hline $70-2,87$ & 17.5 & 4.91 & 40.03 & 1.14 & 0.47 & 1.23 & 0.20 & 1.36 & 142 & 58 & 21 & 57 & 48 & 658 & 20 \\
\hline $71-3,135$ & 24.5 & 6.33 & 37.45 & 1.12 & 0.46 & 1.27 & 0.26 & 1.20 & 311 & 50 & 38 & 40 & 48 & 468 & 22 \\
\hline $71-4,40$ & 62.5 & 14.55 & 0.59 & 2.75 & 1.97 & 2.61 & 0.49 & 4.60 & 1240 & 113 & 48 & 40 & 87 & 205 & 14 \\
\hline $72-4,68$ & 14.5 & 4.25 & 35.94 & 0.82 & 0.48 & 1.15 & 0.16 & 5.70 & 426 & 37 & 19 & 113 & 136 & 684 & 36 \\
\hline $73-2,39$ & 8.5 & 2 & 48.39 & 1.60 & 0.28 & 0.72 & 0.11 & 0. & 1063 & 24 & 10 & 25 & 28 & 695 & 19 \\
\hline $76-2,140$ & 28.5 & 6 & 30.72 & 1.2 & 0. & 1. & 0. & 1 & 2 & 47 & 35 & 38 & 53 & 374 & 18 \\
\hline $77-2,17$ & 20 & 5.95 & 35.94 & 1.66 & 0.48 & 1.36 & 0.24 & 1. & 480 & 74 & 35 & 96 & 54 & 568 & 29 \\
\hline $78-1,62$ & 21 & 6.14 & 32.06 & 5.48 & 0.55 & 1.50 & 0.24 & 1.18 & 432 & 37 & 35 & 38 & 64 & 516 & 21 \\
\hline $79-2,66$ & 20 & 5.67 & 39.32 & 1.09 & 0.46 & 1.57 & 0.27 & 1.16 & 705 & 76 & 23 & 41 & 44 & 421 & 19 \\
\hline 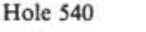 & & & & & & & & & & & & & & & \\
\hline 28 & 20.50 & 5.95 & 36.27 & 1.55 & 2.13 & 1.20 & 0.19 & 1.44 & 1665 & 61 & 25 & 36 & 40 & 45 & 17 \\
\hline $1-2,70$ & 28.00 & 6.71 & 29.59 & 2.38 & 1.86 & 1.78 & 0.21 & 2.7 & 1190 & 71 & 30 & 58 & 54 & 1110 & 31 \\
\hline $2-3,70$ & 22.60 & 5.95 & 35.73 & 1.92 & 1.58 & 1.47 & 0.20 & 1.4 & 905 & 68 & 27 & 51 & 54 & 1070 & 19 \\
\hline $3-3,70$ & 15.60 & 3.78 & 40.04 & 1.28 & 1.38 & 1.10 & 0.15 & 1.78 & 615 & 58 & 19 & 52 & 39 & 1173 & 20 \\
\hline $4-3,60$ & 14.90 & 3.59 & 40.84 & 1.23 & 1.47 & 1.05 & 0.14 & 1.6 & 363 & 42 & 21 & 42 & 39 & 1200 & 17 \\
\hline $5-3,35$ & 38.70 & 7 & 21.85 & 2.53 & 2.06 & 1.81 & 0.20 & 2. & 636 & 74 & 45 & 45 & 59 & 784 & 9 \\
\hline $6-2,115$ & 49.50 & 8.97 & 12.76 & 2.0 & 2.34 & 2.44 & 0.23 & 2. & 510 & 89 & 58 & 79 & 60 & 579 & 17 \\
\hline $13-4,22$ & 16.30 & 3.40 & 41.23 & 1.85 & 1.12 & 0.96 & 0.13 & 2.40 & 484 & 79 & 22 & 62 & 46 & 1205 & 24 \\
\hline $17-2,127$ & 14.90 & 3.40 & 40.91 & 0.85 & 1.08 & 1.12 & 0.13 & 1.30 & 400 & 221 & 16 & 127 & 41 & 1200 & 43 \\
\hline $18-2,65$ & 18.70 & 3.68 & 39.78 & 0.83 & 0.96 & 0.97 & 0.16 & 1.48 & 421 & 58 & 14 & 139 & 1120 & 42 & 13 \\
\hline $28-1,115$ & 6.40 & 1.32 & 48.66 & 0.48 & 0.70 & 0.44 & 0.05 & 0.6 & 579 & 37 & 8 & 28 & 25 & 857 & 16 \\
\hline $29-2,13$ & 35.60 & 7.18 & 23.99 & 0.90 & 2.03 & 2.42 & 0.17 & 1. & 200 & 95 & 27 & 47 & 49 & 821 & 10 \\
\hline $30-\mathrm{CC}, 13$ & 13.30 & 3.59 & 40.76 & 1.85 & 0.77 & 0.63 & 0.17 & 1. & 226 & 68 & 23 & 41 & 29 & 489 & 17 \\
\hline $31-1,29$ & 31.80 & 8 & 23.93 & 3.10 & 1.47 & 0.64 & 0.44 & 3. & 384 & 84 & 97 & 32 & 31 & 389 & 16 \\
\hline $31-2,25$ & 23.90 & 1 & 31.19 & 2. & 1.24 & 0.54 & 0.35 & 3. & 757 & 89 & 119 & 24 & 35 & 274 & 17 \\
\hline $32-2,32$ & 5 & 1 & 50.25 & 0.95 & 0.46 & 0.28 & 0.08 & 0.78 & 189 & 26 & 8 & 20 & 29 & 826 & 12 \\
\hline $33-1,116$ & 9.00 & 2.74 & 47.13 & 0.80 & 0.53 & 0.5 & 0.10 & 0 & 38 & 53 & 10 & 18 & 30 & 473 & 13 \\
\hline $34-1,42$ & 1.60 & 0.47 & 53.60 & 1.28 & 0.23 & 0.08 & 0.01 & 0.10 & 58 & 26 & 3 & 18 & 21 & 579 & 12 \\
\hline $35-1,27$ & 1.40 & 0.38 & 53.99 & 1.25 & 0.28 & 0.07 & 0.01 & 0.10 & 53 & 37 & 2 & 17 & 20 & 573 & 12 \\
\hline $36-1,58$ & 1.30 & 0.57 & 51.38 & 1.70 & 0.36 & 0.11 & 0.01 & 0.10 & 37 & 53 & 4 & 25 & 25 & 1247 & 11 \\
\hline $37-1,44$ & 3.70 & 1.32 & 40.50 & 8.78 & 0.45 & 0.25 & 0.06 & 0.45 & 63 & 47 & 16 & 23 & 26 & 1404 & 11 \\
\hline $39-1,10$ & 5.20 & 1.61 & 47.01 & 0.93 & 0.64 & 0.29 & 0.06 & 0.45 & 53 & 89 & 18 & 56 & 67 & 1041 & 11 \\
\hline $42-2,20$ & 29.50 & 1.04 & 34.80 & 0.88 & 0.78 & 0.20 & 0.02 & 0.23 & 89 & 100 & 13 & 45 & 38 & 694 & 9 \\
\hline $45-1,55$ & 4.30 & 0.66 & 48.69 & 0. & 0.60 & 0.21 & 0.03 & 0 & 42 & 133 & 11 & 52 & 46 & 910 & 12 \\
\hline $47-2,51$ & 7.20 & 1.51 & 44.77 & 0.77 & 0.77 & 0.34 & 0.06 & 0.67 & 16 & 160 & 14 & 63 & 57 & 1075 & 12 \\
\hline $48-1,107$ & 8.40 & 0.57 & 47.40 & 0.71 & 0.57 & 0.16 & 0.02 & 0.26 & 11 & 86 & 5 & 30 & 32 & 906 & 10 \\
\hline $49-1,5$ & 6.00 & 0.38 & 49.92 & 0.73 & 0.62 & 0.13 & 0.01 & 0.21 & 63 & 53 & 4 & 31 & 31 & 632 & 12 \\
\hline $54-1,31$ & 4.00 & 0.94 & 49.15 & 0.80 & 0.37 & 0.20 & 0.04 & 0.46 & 42 & 31 & 7 & 22 & 27 & 437 & 13 \\
\hline $55-1,90$ & 1.20 & 0.28 & 50.41 & 0.70 & 0.41 & 0.09 & 0.01 & 0.14 & 21 & 43 & 3 & 32 & 24 & 621 & 13 \\
\hline $56-3,74$ & 0.80 & 0.19 & 51.60 & 0.74 & 0.37 & 0.08 & 0.00 & 0.16 & 26 & 43 & 2 & 24 & 25 & 521 & 13 \\
\hline $57-3,37$ & 1.50 & 47 & 50.90 & 0.77 & 0.32 & 0.13 & 0.02 & 0 & 58 & 26 & 4 & 25 & 25 & 1263 & 13 \\
\hline $58-2,39$ & 1.00 & 0.19 & 51.60 & 0.70 & 0.42 & 0.09 & 0.01 & 0.13 & 105 & 40 & 2 & 23 & 25 & 484 & 14 \\
\hline $60-2,123$ & 3.60 & 0.85 & 48.27 & 1.54 & 0.34 & 0.24 & 0.04 & 0.45 & 74 & 24 & 7 & 25 & 26 & 505 & 13 \\
\hline $63-2,54$ & 31.10 & 10.39 & 22.70 & 2.12 & 0.88 & 2.37 & 0.45 & 4.32 & 195 & 88 & 51 & 33 & 65 & 253 & 12 \\
\hline $64-1,66$ & 5.60 & 1.51 & 46.52 & 1.41 & 0.39 & 0.52 & 0.07 & 0.66 & 53 & 66 & 10 & 37 & 32 & 437 & 14 \\
\hline $65-1,90$ & 3.00 & 0.85 & 50.02 & 0.76 & 0.35 & 0.25 & 0.04 & 0.37 & 32 & 28 & 4 & 19 & 23 & 500 & 14 \\
\hline $66-1,122$ & 2.40 & 0.76 & 51.14 & 0.74 & 0.34 & 0.19 & 0.03 & 0.30 & 32 & 15 & 2 & 19 & 21 & 521 & 13 \\
\hline $67-2,90$ & 3.00 & 1.04 & 52.12 & 0.78 & 0.25 & 0.27 & 0.04 & 0.45 & 42 & 27 & 5 & 22 & 24 & 411 & 13 \\
\hline $68-1,16$ & 5.70 & 08 & 45.93 & 1.17 & 0.40 & 0.54 & 0.10 & 0.95 & 47 & 43 & 12 & 37 & 34 & 447 & 13 \\
\hline $69-5,21$ & 0.10 & 78 & 43.34 & 1.42 & 0.48 & 0.88 & 0.14 & 1.72 & 47 & 34 & 18 & 29 & 34 & 326 & 16 \\
\hline $71-1,36$ & 19.00 & 6.71 & 33.65 & 2.45 & 0.56 & 1.64 & 0.2 & 3.5 & 253 & 52 & 38 & 33 & 47 & 284 & 17 \\
\hline $72-5,93$ & 7.50 & 2.08 & 48.45 & 1.01 & 0.37 & 0.70 & 0.09 & 0.99 & 100 & 26 & 9 & 22 & 26 & 442 & 14 \\
\hline $74-1,107$ & 2.20 & 0.57 & 51.77 & 1.14 & 0.42 & 0.19 & 0.02 & 0.28 & 37 & 21 & 4 & 21 & 24 & 547 & 13 \\
\hline $76-1,80$ & 3.00 & 0.47 & 51.13 & 0.85 & 0.37 & 0.15 & 0.03 & 0.53 & 53 & 95 & 3 & 21 & 20 & 515 & 13 \\
\hline $77-3,106$ & 14.75 & 4.70 & 40.48 & 1.24 & 0.51 & 1.28 & 0.26 & 2.87 & 153 & 53 & 21 & 31 & 44 & 542 & 16 \\
\hline $78-1,79$ & 14.50 & 4.53 & & 1.22 & 0.54 & 1.30 & 0.28 & 2.72 & 159 & 79 & 22 & 28 & 40 & 673 & 16 \\
\hline $79-1,124$ & 7.00 & 1.98 & 48.71 & 0.96 & 0.37 & 0.59 & 0.12 & 1.33 & 95 & 226 & 9 & 22 & 30 & 515 & 15 \\
\hline
\end{tabular}



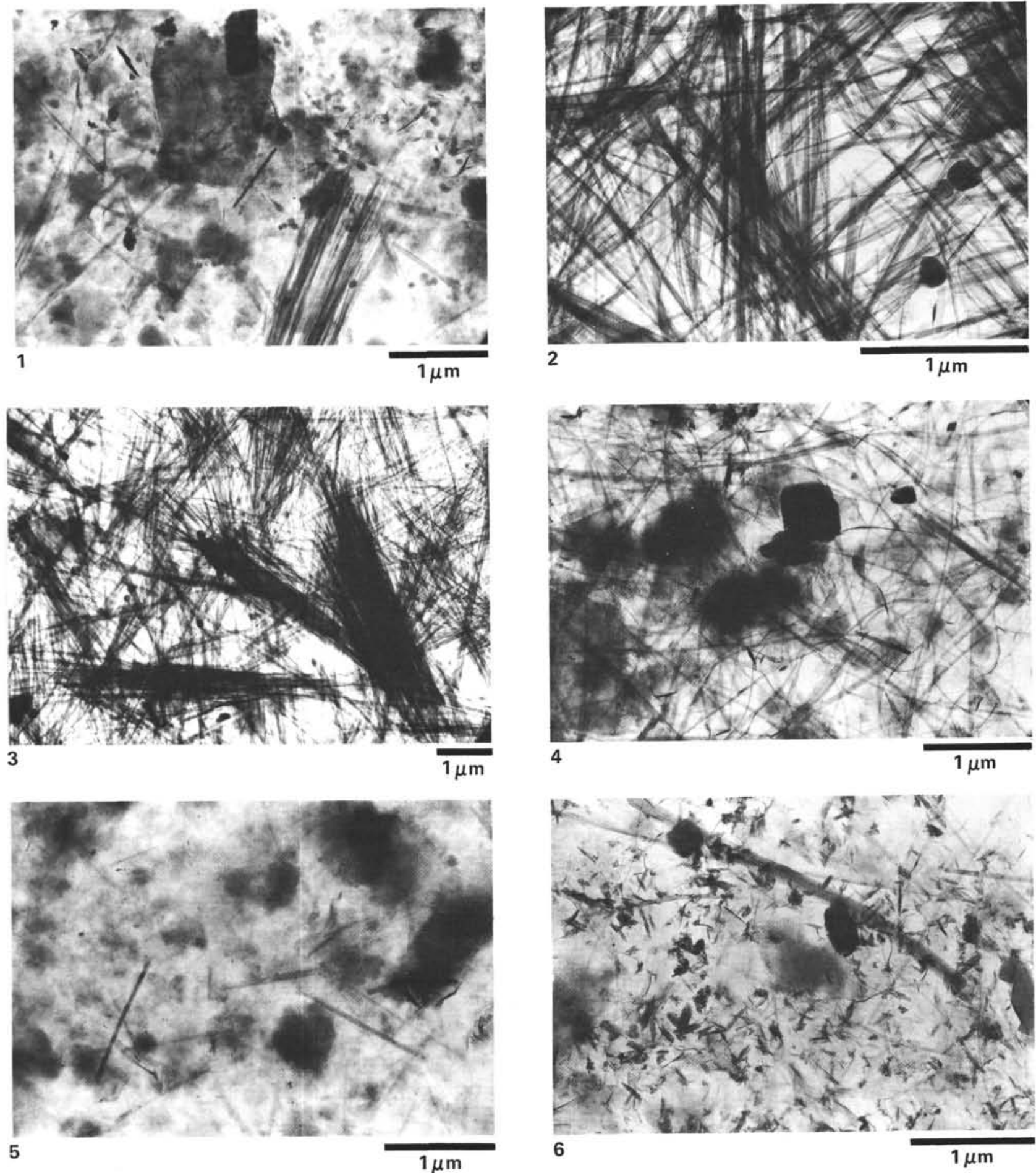

Plate 1. Electromicrographs. 1. 537-11-2, $18 \mathrm{~cm}$, Berriasian(?); illite, chlorite, sepiolite, and palygorskite dispersed among blurred smectite sheets. 2-3. 537-13-1, $8 \mathrm{~cm}$, Berriasian(?); almost exclusively palygorskite, in dense and imbricated bundles. $4.538 \mathrm{~A}-11-1,10 \mathrm{~cm}, \mathrm{O}$ igocene; smectites, flexuous fibrous clays, clinoptilolite plaquettes. 5. 538A-21-3, $130 \mathrm{~cm}$, Late Cretaceous (Coniacian-Santonian?); blurred smectite, short and broken fibers of palygorskite. 6. $538 \mathrm{~A}-21-4,124 \mathrm{~cm}$, Albian(?); abundant smectites, long palygorskite fibers, small goethite aggregates. 

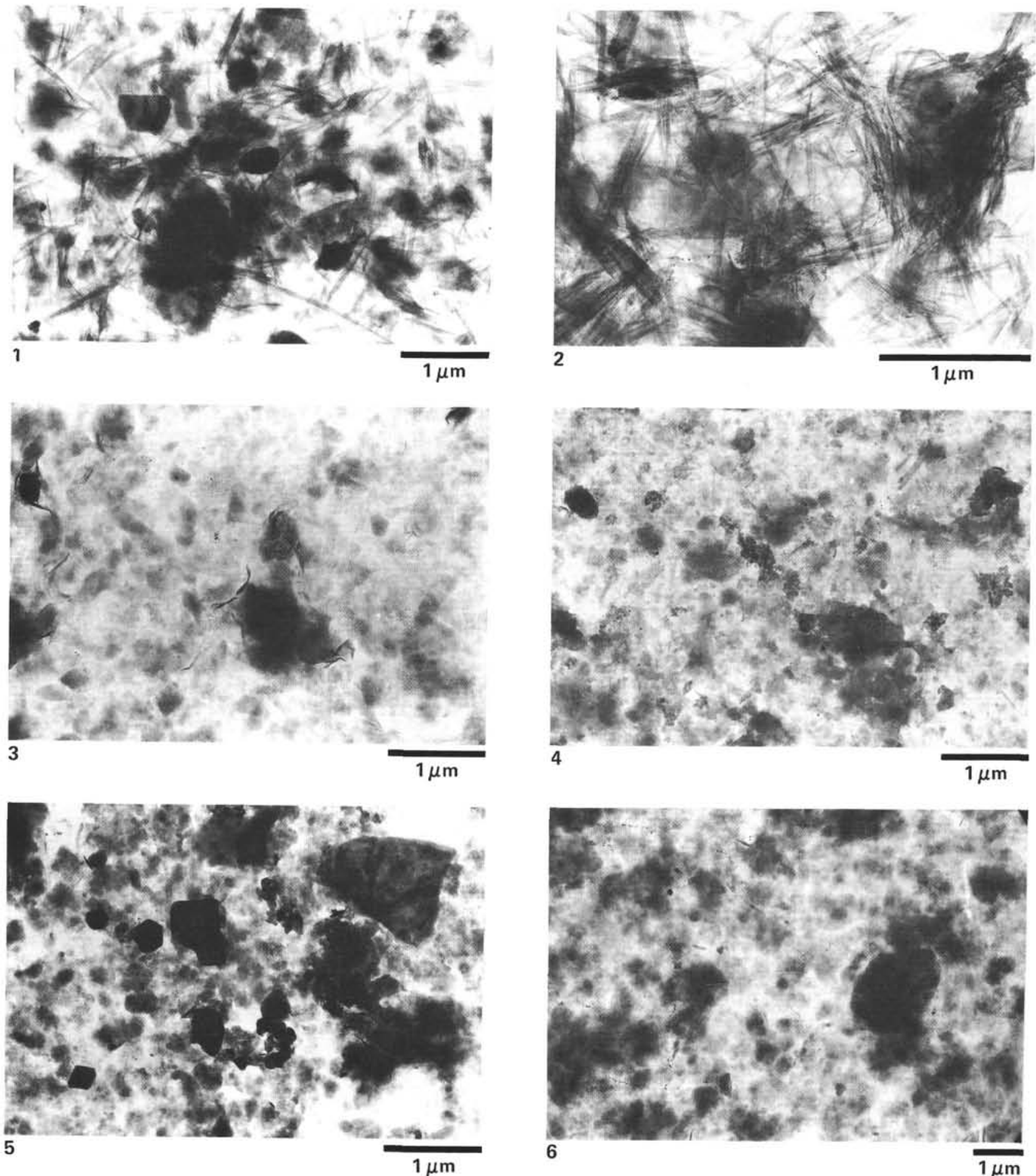

Plate 2. Electromicrographs. 1. 540-5-3, $55 \mathrm{~cm}$, Miocene; smectite, illite, and kaolinite, scattered short and broken fibers of sepiolite and palygorskite. 2. 540-13-4, $22 \mathrm{~cm}$, late Oligocene; abundant sepiolite bundles, smectite sheets. 3. 540-31-1, 29 cm, Late Cretaceous; blurred and cloudy smectite particles. 4. 540-45-1, $55 \mathrm{~cm}$, late Albian; smectite and palygorskite facies; fibers are short and poorly preserved. 5. 54064-1, $66 \mathrm{~cm}$, late Albian; illite and kaolinite facies, with a background of smectites and irregular mixed-layer clays. $6.535-58-2,42 \mathrm{~cm}$, Valanginian; smectite-rich facies, with few illite sheets, typical of a large part of Early Cretaceous sediments. 